\title{
Student Awareness of Costs and Benefits of Educational Decisions: Effects of an Information Campaign
}

\author{
Martin McGuigan \\ London School of Economics \\ Sandra McNally \\ London School of Economics and University of Surrey \\ Gill Wyness \\ London School of Economics and University College London
}

\begin{abstract}
Many students appear to leave full-time education too soon, despite the possibility of high returns from further investment in their education. One contributory factor may be insufficient information about the potential consequences of their choices. We investigate students' receptiveness to an information campaign about the costs and benefits of pursuing postcompulsory education. Our results show that students with higher expected net benefits from accessing information are more likely to avail themselves of the opportunity presented by our experiment. Their intention to stay on in post-16 education is strongly affected by the experiment, though not their intention to apply to university. Effects are heterogeneous by family background and gender.
\end{abstract}

\section{Introduction}

The economic benefits of investing in human capital are known to be high, particularly if students pursue higher education (e.g., Blundell, Dearden, and Sianesi 2005). However, of 16-18-year-olds in England, just under

We are grateful for financial support from the Economic and Social Research Council. We would like to thank Cleveratom Ltd. (particularly Hais Deakin) for developing the website and Charley Greenwood, Robert French, and Jo Cantlay for excellent research assistance. We would like to thank participants of various seminars/conferences for comments: the Centre for Economic Performance, London School of Economics, the Institute for Fiscal Studies, the University of Sheffield, Institute for Social and Economic Research, University of Essex, University College Dublin, University of Sussex, the conference of the Association for Education, Finance, and Policy, and the Royal Economic Society conference. In particular, we would like to thank Emla Fitzsimons, Christopher Jepsen, Eric Maurin, Steve Machin, John Van Reenen, Marcos Vera Hernandez, the editors, and two anonymous referees for helpful comments.

[ Journal of Human Capital, 2016, vol. 10, no. 4]

( 2016 by The University of Chicago. All rights reserved. 1932-8575/2016/1004-0003\$10.00 
30 percent of young people are not in full-time education and about 7 percent are "not in education, training or employment." At the other end of the distribution, about 35-40 percent of young people go to university between the ages of 18 and 20 .

There are many potential reasons why people drop out of full-time education relatively early and why they do not go on to higher education. While this may be a rational and well-informed response to individual circumstances, there is a possibility that at least some young people would have made a different decision had they been better informed about various aspects of pursuing education beyond the compulsory years and about higher education in particular. For example, it may be that young people are not well informed about the costs and benefits of their future educational decisions. If lack of information is the problem, a relatively simple (and inexpensive) policy response is to provide this information in a timely way and encourage students and teachers to access it. This type of intervention has been the subject of a number of recent studies in the economics of education (see Sec. II).

However, it is difficult to compel students to access information if there is some cost for them in doing so. An insight of the literature on financial literacy is that consumers invest in financial knowledge to the point at which their marginal time and money costs of doing so are equated to their marginal benefits (Lusardi and Mitchell 2014). The literature on optimal portfolio management (Ehrlich, Hamlen, and Yin 2008; Ehrlich, Shin, and Yin 2011) suggests that human capital itself raises a person's efficiency in acquiring information. Given that there is a time cost to investing in information processing (even if provided freely) and differential ability in processing information (influenced by preexisting human capital), a real possibility is that career-related information interventions may not be particularly effective at getting to "hard-to-reach" students at risk of dropping out early.

In this paper, we examine the extent to which young people lack good information about the costs and benefits of future educational investment and whether exposure to relevant information affects their knowledge and attitudes. We devise an information campaign, the core of which is a website in which costs and benefits are simply explained. We implement the intervention as a randomized controlled trial in secondary schools in London in which half of schools are exposed to the treatment. ${ }^{2}$ Within the treated schools, we analyze which types of students access the website, under the hypothesis that variables likely to be important for influencing the net benefits of accessing information also influence who uses the web-

\footnotetext{
${ }^{1}$ See https://www.gov.uk/government/uploads/system/uploads/attachment_data /file/436526/Main_text_16-18_participation_SFR19_2015.pdf.

${ }^{2}$ In England, students go to primary school to the age of 11 and transfer to secondary schools until the age of 16 (the end of compulsory full-time education) or 18. This experiment involves students in their penultimate year of compulsory education (when they are aged 14-15). Grade repetition is not permitted.
} 
site. We then analyze both the "intention to treat" effect and the effect of the treatment (i.e., accessing the website) on the treated. Our results show that those with higher expected net benefits of accessing the website (i.e., those likely to gain the most from higher education) are more likely to do so than others, and this leads to a strong effect on many of the measured outcomes of knowledge and future intentions.

However, our fieldwork took place over the period in which the trebling of university fees was announced in England. We show that our information intervention is ineffective for influencing attitudes to cost and the intention of applying to university in the future. Although we cannot prove that it was this announcement (and the extensive media coverage) that mitigated the influence of our information campaign in these respects, we provide suggestive evidence by looking at the control group over the two waves of our survey (conducted 8-12 weeks apart) and show how all outcome variables change over this short period. While those variables that are unlikely to be influenced by the government announcement (and subsequent media coverage) remain largely unchanged, we can see that perceptions of cost increase among control group students, while their intentions to apply to university decline.

Despite this, the information campaign (via the website) is shown to strongly influence the intention to pursue postcompulsory education. Furthermore, we show that this effect is stronger for groups less likely to access the website and more likely to drop out early from full-time education. Specifically, we analyze the effects for a measure of home resources and by gender. The results show stronger effects for students from lower-income backgrounds (i.e., below the median) and for boys. Lessons for policy are that "information campaigns" can be effective in changing minds (at least in the short term), but those who voluntarily access information may not be the group that are potentially most affected by it. The reason may be that such young people have a higher marginal cost of accessing information (e.g., a higher discount rate). Yet these are the groups of most concern to policy makers because of their higher propensities to drop out of education too soon.

The remainder of this paper is structured as follows: In Section II, we give a brief literature survey, drawing on different fields of research to provide a background and context for our study. In Section III, we describe the institutional context in England. In Section IV, we describe our experiment. In Section V, we present a modeling framework. In Section VI, we present our results about who accesses the website and the effect of the treatment before presenting conclusions in Section VII.

\section{Brief Literature Survey}

There is a growing literature in economics about the effect of information on people's attitudes and behavior. In an educational context, relevant papers include Nguyen (2008), Bettinger et al. (2009), Jensen (2010), 
Booij, Leuven, and Oosterbeek (2012), Fryer (2013), Hoxby and Turner (2013), Oreopoulos and Dunn (2013), and Goux, Gurgand, and Maurin (2014). These studies all use an experimental design to test the effects of information on costs and/or benefits of education on attitudes and behavior (albeit in very different contexts). All of these studies find information to have an effect on knowledge and attitudes, but it is more unusual to find an effect on behavior. Exceptions are two studies on developing countries (Nguyen 2008; Jensen 2010), Hoxby and Turner (2013) for the United States, and Goux et al. (2014) for France. ${ }^{3}$ Hoxby and Turner (2013) evaluate the impact of providing high-achieving, low-income students with semicustomized information on the application process and college net costs (as well as waivers for application fees). They find this to have a strong impact on enrollment in selective colleges and early evidence that these students do as well in these colleges as they would have done elsewhere (in terms of freshman grades). A study in Paris focuses on providing information and relatively light-touch career advice to students at risk of dropping out of education after middle school (Goux et al. 2014). This is shown to have a positive effect on the probability of enrolling in vocational programs as opposed to repeating a grade or dropping out of education altogether. There are also other (noneducational) contexts in which information provision is shown to have an effect on actual behavior in developed countries: information about pensions on retirement behavior in the United States (Duflo and Saez 2003) and information about Social Security provisions on labor market participation in the United States (Liebman and Luttmer 2010).

This study also links with a literature about how much students know about wages. For example, Betts (1996) and Dominitz and Manski (1996) are two early studies in this literature. They elicit future wage expectations of university students. Although students do anticipate positive returns to education, there is considerable heterogeneity and it is common to overestimate returns. A study by Wiswall and Zafar (2011) also finds that even very high-ability students (in this case enrolled at an elite US university) have biased beliefs about the distribution of earnings in the population and that students revise these beliefs (and subsequent choices) in response to information.

The literature on financial literacy is also relevant to this study, which looks at the question of how people acquire and deploy financial literacy (reviewed by Lusardi and Mitchell [2014]). This casts financial knowledge as a form of investment in human capital. It defines "financial literacy" as people's ability to process economic information and make informed decisions about financial planning, wealth, accumulation, debt,

\footnotetext{
${ }^{3}$ In another US study, Bettinger et al. (2009) find that information is effective only when combined with practical assistance with regard to loan applications. Information on its own is ineffective.
} 
and pensions. Human capital can affect the information acquisition process. For example, Ehrlich et al. (2008, 2011) show that optimal management of portfolios that include risky assets requires the use of time, effort, and knowledge and that more educated households are more likely to invest in risky assets and to have higher overall returns. This literature has relevance for this study because in this case people are being invited to access knowledge that will improve their future investments (i.e., in terms of future payoff to education and how to finance this); but they access the knowledge voluntarily and not because it is forced on them (even though teachers may encourage students to access the website more in some schools than in others).

Models of financial literacy suggest that consumers invest in knowledge to the point that marginal benefits equate with marginal costs (which will depend on the cost function for financial knowledge acquisition); some subgroups will rationally choose to not invest in financial knowledge because acquiring financial knowledge can be expensive (in terms of time and money), and greater financial sophistication will not benefit everyone. However, Lusardi and Mitchell (2014) argue that despite the fact that some people will rationally choose to invest little or nothing in financial knowledge, it can still be socially optimal to raise financial knowledge for everyone early in life, as even if the least educated let their knowledge endowment depreciate, they will still earn higher returns on their saving. Evidence on financial literacy in the United States suggests that poor knowledge is widespread and strongly correlated with education, although there remains substantial heterogeneity within education groups.

Finally, the ideas of "rational inattention" models also have relevance here (e.g., Sims 2010; Matêjka and McKay 2015). These models consider how agents make decisions about how to process information. "Information processing" is costly in that it requires effort and diverts attention from other topics. Sims (2010) argues that a person has a finite amount of attention - or capacity for processing information - to devote to a number of things. The cost parameter reflects the shadow cost of allocating attention to the decision being considered. Such models explain why some freely available information is not used or is imperfectly used.

When we develop a conceptual framework for why only some students choose to access the website, the insights from the literature on financial literacy and rational inattention models are highly pertinent, in addition to standard models for education investment decisions that emphasize the importance of cognitive ability and more recently noncognitive abilities (e.g., Heckman, Stixrud, and Urzua 2006).

\section{The Institutional Context}

In England, compulsory school education lasts up to age 16. During their final compulsory school year (year 11), students plan whether to continue 
with their education, with what provider, and in which subjects. ${ }^{4}$ After year 11, they might pursue either an academic or a more vocational route either in school or in a further education college. The typical route to higher education (university) is to study three specialist subjects at A-level and then apply to university 2 years later. This is pursued by about 40 percent of the cohort, with about 30 percent applying to university 2 or 3 years later. The remainder are more likely to spend some time in a further education college, which typically leads to a vocational qualification. ${ }^{5}$ This study surveys students at age 15 , their penultimate year of compulsory schooling.

As a result of rapid expansion in the number of students going to university over recent decades, the government has implemented a series of major funding policy changes. In particular, England has moved from a situation in which higher education was free of charge to all students to a system in which students are expected to contribute a significant proportion of the cost of their education.

Tuition fees were first introduced to England in 1998. The fees (of up to $£ 1,000$ per year) were payable up-front and means-tested according to parental income. In 2006, up-front fees were abolished and replaced by a deferred £3,000 fee, payable by all regardless of parental income but fully covered by a fee loan with quite generous terms. The "Browne Review" reported in October 2010 and recommended that the tuition fee cap should be removed altogether. ${ }^{6}$ The government response to the review came shortly afterward, in November 2010, with the announcement that fees would not be unlimited but would instead be capped at $£ 9,000$ per year. As previously, the fees would be income contingent and payable after university over a certain income threshold.

These events received huge press coverage, much of which focused on the potential negative effect of the fee increases on student participation. ${ }^{7}$ The media coverage on tuition fees is illustrated in figure 1 . The figure shows the number of hits on the BBC website mentioning tuition fees between January 2010 and May 2011. The fee increases met with a great degree of public anger, and a mass protest of tens of thousands of students and lecturers took place in November 2010. Nevertheless, the rise in tuition fees was successfully passed through Parliament in December 2010. The time of these events is relevant to our study because it can be expected to influence students' knowledge of university fees and their attitudes to cost. Media coverage has tended to focus on the head-

\footnotetext{
${ }^{4}$ From summer 2014, students are compelled to stay on in some form of education or training (not necessarily full-time or at school) until the age of 18 .

${ }^{5}$ More detail is provided by Hupkau et al. (2016).

6 The Browne Review is formally titled "Securing a Sustainable Future for Higher Education in England" and is available at http:// hereview.independent.gov.uk/hereview/report/.

7 See, e.g., J. Vasagar and J. Shepherd, "Willetts Announces Student Fees of Up to $£ 9,000$," Guardian, November 3, 2010; "Coalition Plot to Blow Up Education: Nick Clegg Faces Student Leader’s Anger at $£ 9,000$ Cap on Tuition Fees,” Daily Mail, November 4, 2010.
} 


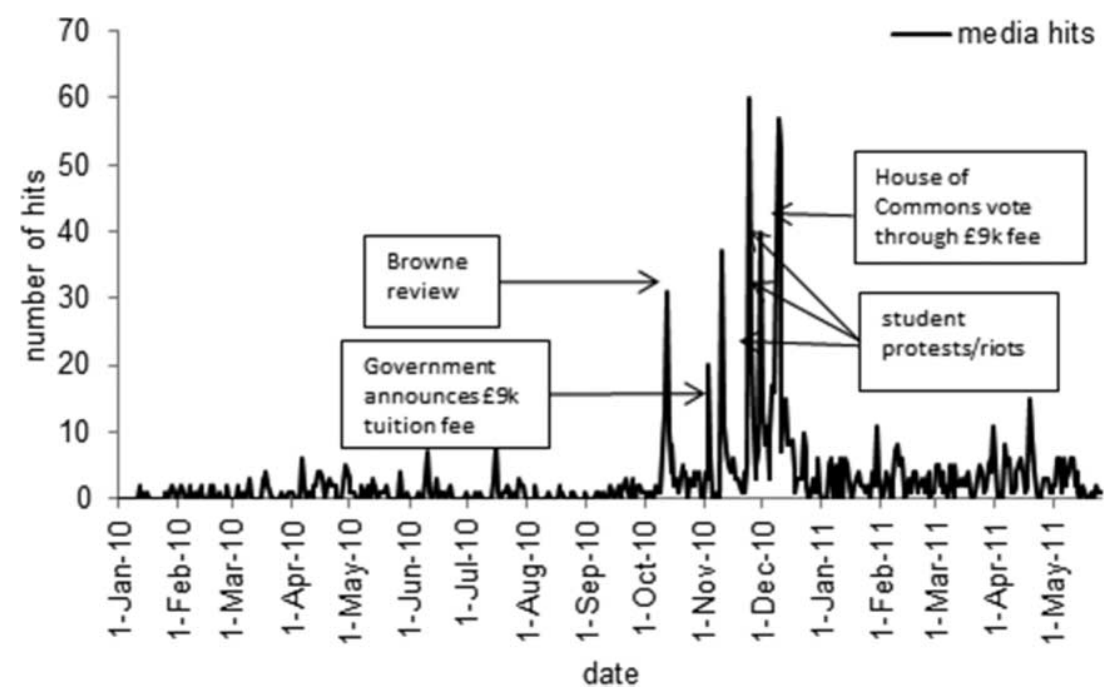

Figure 1.-Media reports of tuition fees: count of news articles mentioning "tuition fees" on the BBC website from January 2010 to May 2011.

line debt figure rather than the complexities of the loan repayment system. That the complexity of the system might be an issue is supported by work from Scott-Clayton (2012) for the United States. ${ }^{8}$ Her review of the information constraints faced by college students argues that complexity is a great obstacle to the effectiveness of student loan programs.

\section{The Experiment}

\section{A. Randomization}

Our study took place mainly over the academic year $2010-11 .{ }^{9}$ All secondary schools in London were invited to participate. We conducted paired randomization in which we aligned schools in sequence on the following dimensions: ${ }^{10}$ independent/selective or comprehensive, single-sex or mixed, and average exam scores in the General Certificate of Secondary Education (GCSE) exam at age 16. We randomized schools for the treat-

\footnotetext{
${ }^{8}$ However, the UK system is less complex than in the United States (where there is much more price variation - particularly given the prevalence of private universities, which are still rare in the United Kingdom). What both systems have in common is a heavy reliance on student loans.

${ }^{9}$ Some schools (not included here) took part in a pilot the previous academic year, and two schools participating toward the end of the academic year $(2009 / 10)$ are included in the main sample here.

${ }^{10}$ Since statistical efficiency drops when randomizing clusters, we pair schools on the basis of their pretreatment characteristics (see, e.g., Angrist and Lavy 2009). We then randomly assign one school within each pair to receive the treatment.
} 
ment within each pair of schools. Table 1 shows how the randomization worked on the basis of school-level characteristics. The table shows that values for the treatment schools are very similar to those of the control schools at baseline.

There are 54 schools in our main sample, which is about 10 percent of all schools in London. We survey all students in year 10 (which comes to 6,614 students in total). The participating schools were more likely than other schools to be independent/selective, have higher average performance, and have a lower percentage of students eligible to receive free school meals. Thus, they cannot be taken to be representative of the school population. We might expect students in schools with more favorable observable characteristics to be better informed about costs and benefits of educational choices than students in other schools. Given that the selection is probably toward schools that provide better information on careers, the findings reported below (on serious deficiencies in knowledge) do not bode well for schools outside the sample. We choose students in year 10 as the treatment group (i.e., aged 14/15) because this is the penultimate year of compulsory education (year 11 is an exam year, and therefore, it is more difficult to arrange surveys during class time). The future educational career of students is strongly influenced by how they perform in the exams in year 11 (particularly in English and math). During year 11, they also have to think carefully about how they want to specialize the following year. Thus year 10 is a time when students still have a wide range of options, and it was therefore judged to be a good stage at which to implement the information experiment.

TABLE 1

Characteristics OF InVITED SchOOLS

\begin{tabular}{|c|c|c|c|c|}
\hline & $\begin{array}{l}\text { All Schools } \\
\text { Invited }\end{array}$ & $\begin{array}{l}\text { Treatment } \\
\text { Schools }\end{array}$ & $\begin{array}{l}\text { Control } \\
\text { Schools }\end{array}$ & $\begin{array}{c}\text { Difference } \\
\text { between } \\
\text { Treatment } \\
\text { and Control* }\end{array}$ \\
\hline Number of schools & 515 & 27 & 27 & \\
\hline GCSE points score & 424 & $445(83)$ & $438(107)$ & $6.92(18)$ \\
\hline $\begin{array}{l}\text { Proportion with } 5 \text { or more GCSE } \\
\text { grades at } A^{*}-\mathrm{C} \\
\text { Proportion with } 5 \text { or more GCSE } \\
\text { grades at } A^{*}-\mathrm{C} \text { (including }\end{array}$ & .77 & .84 & .80 & .04 \\
\hline English and math) & .55 & .62 & .62 & 0 \\
\hline All-girls's school & .24 & .37 & .37 & 0 \\
\hline All-boys' school & .14 & .19 & .19 & 0 \\
\hline $\begin{array}{l}\text { Independent ( } 15 \text { schools) or } \\
\text { academically selective state } \\
\text { schools ( } 3 \text { schools) }\end{array}$ & .24 & .33 & .33 & $-.04(.06)$ \\
\hline $\begin{array}{l}\text { Proportion eligible for free } \\
\text { school meals }\end{array}$ & .17 & .12 & .16 & $-.04(.04)$ \\
\hline
\end{tabular}

Note.-Standard errors are in parentheses.

* Treatment and control differences in 2009. 


\section{B. Logistics}

In the letter of invitation, we explained that the purpose of the study was to learn about how much students know about economically relevant facts with regard to pursuing postcompulsory education. As an incentive to participate, we promised each school that we would give it resource materials on this issue at some stage during the academic year (without saying when) and that we would give it a school-level report profiling its students compared to similar schools involved in the study. All participating schools were expected to give us 40 minutes of class time on two occasions during the school year (8-12 weeks apart) to survey all students in year 10 (i.e., 14/15-year-olds). Attrition is not an issue in this study.

In each school we set up a meeting with relevant teachers in all the participating schools (regardless of treatment status), and we explained logistical aspects of surveys, which were to be conducted under exam conditions. We prepared a short introductory video to be shown to students before completion. We also sent a representative to every school on the day of the survey.

The first survey was scheduled at a time convenient to the school. We asked only that the second survey should be $8-12$ weeks after the first survey in each participating school. These surveys were time-tabled to take place mainly during the first two terms of 2010/11.

\section{The Treatment}

The central component of the information package was a specially designed password-protected website (Whats4me), which we designed to include important information about the costs and benefits of pursuing postcompulsory education, including simple information about wage premia and employment prospects (derived from the Labour Force Survey between 2000 and 2009 for those aged 30-35) as well as information about university tuition fees, maintenance grants, and loans (which we updated as and when information changed).

We developed other materials that could be used to complement or substitute for the website. This included a one-page leaflet with key information about the benefits and costs of higher education, a 5-minute video that featured images and charts from the website, and a PowerPoint presentation that could be used as a lesson to give to students. We also gave teachers access to the website and a school code that would allow access to anyone in the school. As the experiment is now over, the website has been converted to an open-access website (http://www.whats4.me.uk/). Other materials used as part of the experiment can be downloaded from this website (including the questionnaires completed by students). See online appendix D for a sample of the information provided.

We initially encouraged students to access the website via e-mail. After the first couple of weeks, we sent all the other materials to teachers and encouraged them to use the website. Very few students accessed the web- 
site in the first 2 weeks, that is, with only prompting from the researchers. The proportion accessing the website went up from 4 percent to 16 percent when teachers became involved, indicating the importance of involving teachers and schools in information campaigns. In all but one treatment school, at least some students did access the website. We were unable to monitor the extent to which teachers actually used the material. However, in a series of questions from the two surveys, we measure the extent to which the information campaign changes whether students talk to various people about plans for studying in the future. The only significant effect is an increase in the probability that students talk to teachers about future study plans as part of a lesson (an increase of 5 percentage points, from a baseline of 40 percent).

We show two sets of estimates. First, we show whether there is an average effect of being assigned to the experiment (i.e., students in schools who are randomized to receive the information package compared to those who are not). This is the "intention to treat" effect. While it reflects the effect of the experiment, it does not necessarily reflect the impact of receiving and absorbing information. Some students may have ignored our information package because they had already received similar information. The intention to treat effect will not capture the (positive) effect such information might have had on such students if they had not been able to acquire it elsewhere or had it been provided earlier. Other students may not be interested in acquiring information because they have already made up their minds not to pursue additional schooling and thus might dismiss the information package as irrelevant for them. And then there will be another group of students for whom the expected net benefit from acquiring information is not positive (discussed in Sec. V) or who find it difficult to process the information made available. They will choose not to access the website. To get a sense of the effect of the treatment on those students who actually choose to receive the information package, we present a second set of estimates based on "treatment on the treated," where accessing the website is interpreted as the "treated." This assumes that students taking the intervention seriously would have accessed the website, which was the core part of the intervention. ${ }^{11}$ Estimating this effect involves predicting who will access the website on the basis of the random assignment of schools to the intervention (i.e., using an instrumental variable strategy). Of course this estimate will reflect the effect of the intervention on only a specific subgroup: those interested in accessing information. One would expect the effect of the treatment to be larger on those willing to use the website. Thus the treatment on the treated estimate should be bigger than the intention to treat estimate.

\footnotetext{
11 A larger group of students might have taken the information seriously through other aspects of the treatment (such as the one-page leaflet provided to treatment schools or the PowerPoint slides given to the teacher) even if they did not access the website. One might speculate that the effect of the treatment on these students might lie somewhere in between the intention to treat effect and the treatment on the treated effect.
} 
In table 2, we show prepolicy differences in the full set of outcome variables used in this study (which are described fully in App. A). They cover sets of questions on $(a)$ knowledge of student finance, $(b)$ perceived importance of financial constraints, $(c)$ opportunity cost, $(d)$ knowledge about the benefits of staying on, $(e)$ estimates of costs and benefits, and $(f)$ future intentions. The averages for treatment and control schools are all similar at baseline and never statistically different from each other. Within treated schools, those who access the website are similar to those who do not on many dimensions. However, those who access the website have a lower expected opportunity cost (from going to university), have better prior knowledge in some dimensions (although the only significant difference is on the question about earnings by subject, i.e., "will earn about the same no matter what subject I study"), and are more likely to plan to stay in full-time education beyond the age of 16 and to apply to go to university at some stage (i.e., "very likely will ever apply to university to do a degree"). We now describe a modeling framework for who accesses the website and how we estimate the impact of accessing the website on outcome variables.

\section{Modeling Framework}

Following our discussion of models of the acquisition of financial literacy and rational inattention models (in Sec. II), we consider the decision to use the website developed here as a form of human capital investment.

In the background there is a simple model of human capital accumulation proposed by Rosen (1977): when making decisions about educational investment, individuals who differ in ability, $A$, maximize the present value of lifetime earnings $(y)$. They compare benefits with costs in making decisions about how much schooling $(s)$ to acquire. Thus

$$
y=f(s ; A) .
$$

This benefit-cost decision regarding how much schooling $(s)$ to acquire involves estimating the discounted value of schooling net of forgone earnings (i.e., the opportunity cost for time they could have spent in the labor market). This will be influenced by the price of the skills acquired at school, the interest (discount) rate, and the ability of the individual. The benefit of schooling is increasing in both ability and the price of skills acquired and decreasing in the interest rate. This basic model has been developed in many ways. For example, noncognitive skills and motivation are known to influence schooling decisions and earnings (e.g., Heckman et al. 2006). Family background also plays a major role, both via its role in the formation of human capital at every stage in the life cycle and potentially through the cost (e.g., families compensating for imperfect capital markets by helping to finance postcompulsory education for their children).

A student considering whether or not to invest in acquiring information about potential future education might be regarded as influenced 
by the same factors that determine whether that investment will actually be made. For example, the anticipated value of information might be positively influenced by the student's cognitive and noncognitive abilities and motivation and the expected price of skills in the labor market. Conversely, the decision to invest in acquiring information will be negatively influenced by cost. Since access to the website is free, the cost of relevance is the opportunity cost of time. As noted in the rational inattention framework (e.g., Sims 2010), information processing is costly in that it requires effort and diverts attention from other topics. "Rationally inattentive agents" process information they find useful and ignore information that is not worth the effort of acquiring and processing. We posit that the opportunity cost of time depends on the extent to which individuals are impatient or present oriented (i.e., high discount rates) and the speed at which they can process information (which depends on ability).

Thus, individuals will decide whether or not to access the website (Access) on the basis of a comparison of their marginal cost (i.e., time) and marginal benefit: individual $i$ will choose to access the website as long as the marginal benefit (MB) from doing so is at least equal to the marginal cost (MC):

$$
\text { Access }_{i}=1 \quad \text { if } M B_{i} \geq M C_{i} .
$$

The benefits depend on students' expectations about the usefulness of the information, which depends on the same factors that influence educational investment decisions (i.e., cognitive and noncognitive abilities, motivation, and family background). The costs depend on individuals' discount rate and the speed at which they can process information, which again depends on cognitive abilities.

Using this framework, we estimate a reduced-form model of the decision to access the website:

$$
\operatorname{Access}_{i s}=\beta_{0}+\beta_{1} A_{i s}+\beta_{2} P_{i s}+\beta_{3} F_{i s}+\beta_{4} O_{i s}+\beta_{4} \text { Pair }_{s}+\mu_{i s} .
$$

Whether individual $i$ accesses the website in school $s$ is function of a vector of abilities $A$ (cognitive and noncognitive), the extent to which the individual is present oriented $(P)$, family background $(F)$, and personal characteristics that might affect costs and benefits of obtaining additional information $(O)$. Pair is a dummy variable for each school pair (there are 27 pairs in which one school is randomly assigned to treatment). We also estimate this model within treatment schools and control for school fixed effects (as teachers may be more enthusiastic about the experiment in some treatment schools than in others).

As the benefit of investing in schooling is influenced by ability, so too will be the perceived benefit of acquiring information about future schooling. Furthermore, student ability influences the speed at which information can be processed (and thus affects the cost of acquiring information). We measure cognitive ability using proxies such as students' 


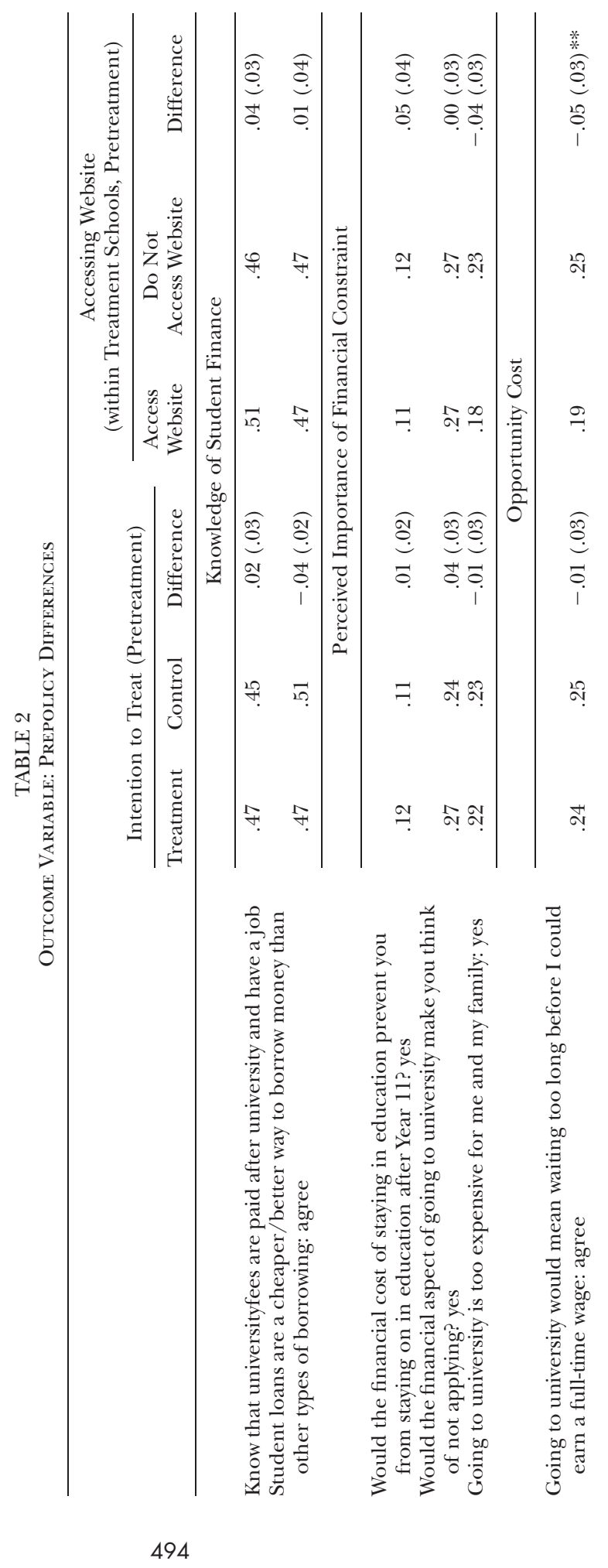




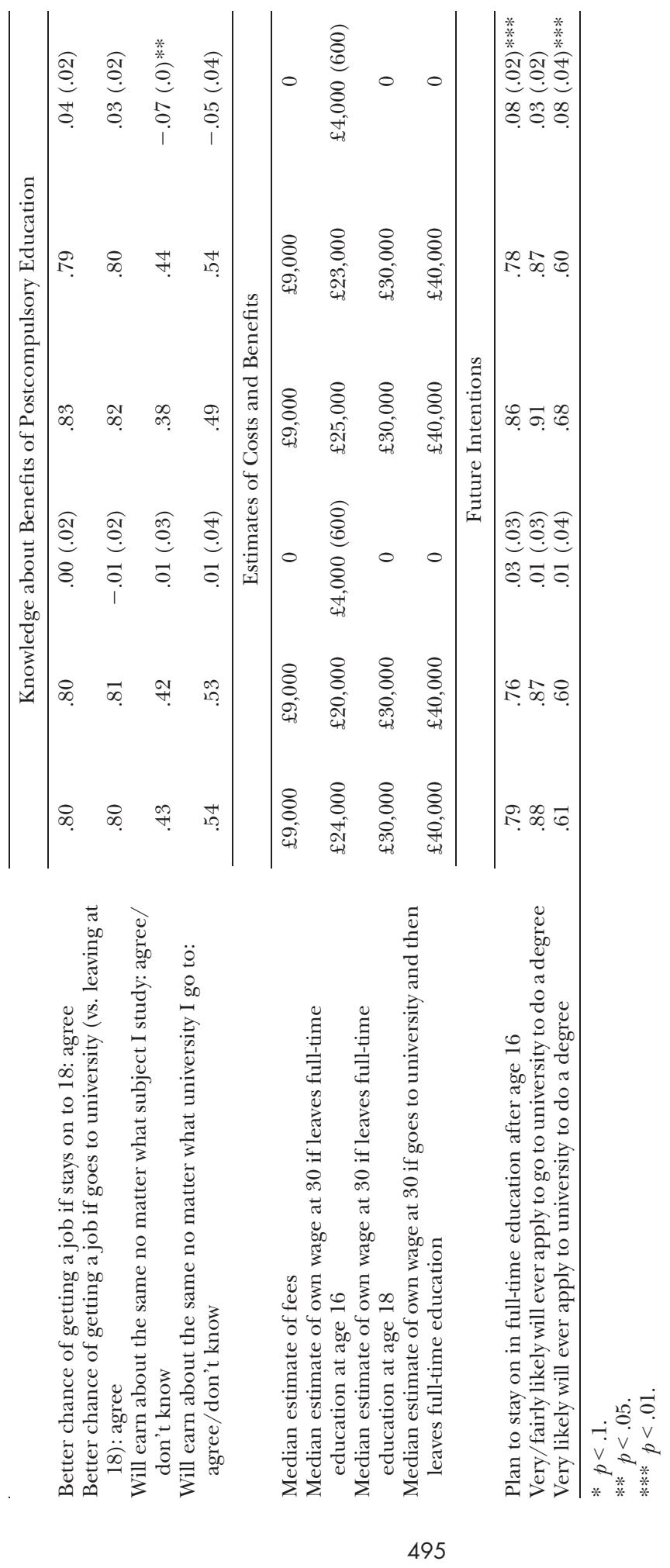


self-assessed ability. For the full sample, we have information on whether the individual considers himself or herself to be good at math and English and whether he or she likes these subjects (which also capture preferences). For a subsample, we have teacher-assessed performance in math and English the previous year. Our preferred methodology is to use the full sample because otherwise we lose 40 percent of our observations and the treatment and control schools are not well matched in terms of baseline characteristics. However, we show that teacher assessment on math and English makes little difference to our regression results. Measures of noncognitive abilities include self-esteem and locus of control. The measure of self-esteem is constructed from student responses to seven questions inquiring about their perceptions of their own self-worth. The locus of control is a six-item index scale constructed from responses to questions that inquired about the amount of control students had over their own lives. Both questions are adopted from the (US) National Education Longitudinal Study of 1988 and are detailed in Appendix B, along with other variables that we use in this analysis.

We measure the degree to which students are present oriented by their response to the question "if you were offered $£ 1,000$ today or $£ 1,100$ in one year's time, what would you prefer?" Students with high discount rates have a higher opportunity cost of time. Thus, one might expect students who are more present oriented to invest less time in acquiring information about the future consequences of educational investment.

We measure family background by books in the home, which is often used as a measure of family resources. One might expect family background to influence educational investment decisions because of its role in the formation of human capital (which is increasing in the family's assets) and because better-off families can help to alleviate credit constraints. This might increase the perceived net benefits of acquiring information about future educational options. Finally, we include gender and whether the individual "talks a lot to teachers/friends/family" about careers. The latter might positively influence the amenability of students to further information and the extent to which this is easily processed.

Having considered factors that influence whether individuals access information, we then estimate both the intention to treat effect from our experiment and the treatment on the treated effect. The latter involves using randomly assigned treatment status to predict whether or not the individual accesses the website. Thus, we estimate (posttreatment)

$$
Y_{i s}=\alpha_{1} T_{s}+\alpha_{2} \text { Pair }_{s}+\varepsilon_{i s},
$$

where $Y$ is the aspect of knowledge/aspirations being asked of student $i$ in school $s, T_{s}$ is whether school $s$ is assigned treatment status, and Pair is a dummy variable for each school pair (there are 27 pairs in which one school is randomly assigned to treatment). The intention to treat effect is given by $\alpha_{1}$. 
Then we estimate

$$
Y_{i s}=\varphi_{1} \text { Access }_{i s}+\varphi_{2} \text { Pair }_{s}+\lambda_{i s},
$$

where $\varphi_{1}$ is the instrumental variable (IV) estimate of the effect of accessing the website on the outcome variables. It represents a "local average treatment effect" (LATE) because the coefficient reflects the impact of accessing the information only on students who actually use the website (which is not necessarily the same as the average effect had all students in treatment schools accessed the website). Thus, we can infer that the effects pertain mainly to students with characteristics that had a stronger probability of accessing the website (outlined above). As we have an instrument that strongly predicts access to the website (i.e., random assignment of the treatment), we should not expect $\varphi_{1}$ to be sensitive to the inclusion of variables that influence access to the website (i.e., in [1]). However, we show regressions in which such variables are included.

We look more closely at the determinants of students' future education intentions: whether a student intends to stay on in full-time education beyond the age of 16 and whether he or she intends to apply to university to do a degree. Thus we show a specification similar to (1) in which the dependent variable represents student intentions rather than access to the website. As these intentions foreshadow future educational investment decisions, one would expect the same variables to be relevant for the reasons described above. This also helps to put the estimate of the effect of accessing the website (at a point in time) in a wider context.

\section{Results}

A. Who Accesses the Website?

As discussed in Section IV, 16 percent of eligible students (i.e., those in treated schools) access the website. In this section, we estimate model (1) to understand to what extent measured characteristics influence the probability that students access the website. The included variables are chosen in an attempt to proxy underlying factors that influence students' costs and benefits of using their time in this way, such as cognitive skills and tendency to discount the future (as discussed in Sec. V).

In table 3 , we show the results of estimating model (1).$^{12}$ Column 1 controls for the school pair (i.e., within which randomization to treatment status was assigned). Column 2 estimates the regression only within treatment schools (since only students within these schools had the option to access the website) and additionally controls for school fixed effects. Column 3 repeats this regression for the subsample of students that can be

\footnotetext{
12 Estimates from a probit model (i.e., marginal effects computed at the average values) suggest almost exactly the same magnitude for estimated effects from a linear probability model for col. 1. Results are available on request.
} 
TABLE 3

Whether Accesses Website

\begin{tabular}{|c|c|c|c|}
\hline & $\begin{array}{l}\text { OLS } \\
(1)\end{array}$ & $\begin{array}{l}\text { School Fixed } \\
\text { Effects } \\
(2)\end{array}$ & $\begin{array}{c}\text { As Col. 2: Only } \\
\text { Schools That Can } \\
\text { Be Linked to } \\
\text { Administrative Data } \\
\text { (3) }\end{array}$ \\
\hline Good at math & $\begin{array}{l}.01 \\
(.01)\end{array}$ & $\begin{array}{l}.01 \\
(.02)\end{array}$ & $\begin{array}{c}.04 \\
(.03)\end{array}$ \\
\hline Good at English & $\begin{array}{c}-.02 \\
(.01)\end{array}$ & $\begin{array}{c}-.01 \\
(.02)\end{array}$ & $\begin{array}{l}-.01 \\
(.02)\end{array}$ \\
\hline Likes math & $\begin{array}{l}.02 * * * \\
(.01)\end{array}$ & $\begin{array}{l}.04 * * * \\
(.01)\end{array}$ & $\begin{array}{l}.04^{*} \\
(.02)\end{array}$ \\
\hline Likes English & $\begin{aligned}-.00 \\
(.01)\end{aligned}$ & $\begin{array}{l}.00 \\
(.01)\end{array}$ & $\begin{array}{l}.02 \\
(.02)\end{array}$ \\
\hline Locus of control & $\begin{array}{l}-.01 \\
(.01)\end{array}$ & $\begin{array}{l}-.03 * * \\
(.01)\end{array}$ & $\begin{array}{l}-.04 * * \\
(.01)\end{array}$ \\
\hline Self-esteem & $\begin{array}{l}.02 * * \\
(.01)\end{array}$ & $\begin{array}{l}.03^{* *} \\
(.01)\end{array}$ & $\begin{array}{l}.01 \\
(.01)\end{array}$ \\
\hline Present oriented & $\begin{array}{l}-.01 \\
(.01)\end{array}$ & $\begin{array}{l}-.01 \\
(.01)\end{array}$ & $\begin{array}{l}-.02^{*} \\
(.01)\end{array}$ \\
\hline Books in the home & $\begin{array}{l}.01^{*} \\
(.01)\end{array}$ & $\begin{array}{l}.02 * * \\
(.01)\end{array}$ & $\begin{array}{l}.02 * * \\
(.01)\end{array}$ \\
\hline Male & $\begin{array}{l}-.05^{* *} \\
(.02)\end{array}$ & $\begin{array}{l}-.05^{* *} \\
(.02)\end{array}$ & $\begin{aligned}-.06^{*} \\
(.03)\end{aligned}$ \\
\hline $\begin{array}{l}\text { Talks a lot to teachers/friends/ } \\
\text { family about careers }\end{array}$ & $\begin{array}{l}.00 \\
(.01)\end{array}$ & $\begin{array}{l}.02^{* *} \\
(.01)\end{array}$ & $\begin{array}{l}.03 * * \\
(.01)\end{array}$ \\
\hline $\begin{array}{l}\text { Whether eligible to receive free } \\
\text { school meals }\end{array}$ & & & $\begin{array}{l}-.02 \\
(.02)\end{array}$ \\
\hline $\begin{array}{l}\text { Whether achieves "expected level" } \\
\text { in English (teacher assessment, } \\
\text { age 14) }\end{array}$ & & & $\begin{array}{l}.01 \\
(.03)\end{array}$ \\
\hline $\begin{array}{l}\text { Whether achieves "expected level" } \\
\text { in math (teacher assessment, } \\
\text { age 14) }\end{array}$ & & & $\begin{array}{c}-.01 \\
(.02)\end{array}$ \\
\hline $\begin{array}{l}\text { Observations } \\
R^{2}\end{array}$ & $\begin{array}{l}5,534 \\
.11\end{array}$ & $\begin{array}{l}2,943 \\
.26\end{array}$ & $\begin{array}{l}1,729 \\
.11\end{array}$ \\
\hline
\end{tabular}

Note.-Full variable descriptions are provided in App. B. Standard errors are clustered at the school level. In cols. 1, 2, and 3, there are 54, 27, and 18 clusters, respectively. Robust standard errors are in parentheses.

$* p<.1$.

$* * p<.05$

$* * * \quad p<.01$.

linked to administrative data. The latter estimates allow us to include variables that measure the teacher's assessment of the student in the previous school year in math and English. They also allow us to measure whether the student is eligible to receive free school meals.

As discussed above, one would expect students with higher levels of cognitive and noncognitive ability to perceive a higher benefit from acquiring information about future schooling decisions and to be better able to process information. The regression results partially support this. 
For example, the probability of accessing the website is positively related to whether the student likes math (which could be considered a proxy for ability as well as reflecting a preference toward study). However, the other measures of cognitive ability (i.e., liking English, self-assessed ability at English and math, teacher assessment of English and math) do not have any additional impact.

Of the measures of noncognitive ability (i.e., self-esteem and locus of control), self-esteem has the expected positive association (for the full sample, in cols. 1 and 2) with accessing the website. Students with higher self-esteem are more likely to seek out information by accessing the website. On the other hand, locus of control has a negative association, which seems counterintuitive: students who believe they have more control over their lives are less likely to use the website.

The measure of family resources (books in the home) has a consistent positive association with accessing the website, as one would expect because better-off families have had more opportunity for prior investment in their children's human capital and may be able to alleviate credit constraints. Such students are more likely to find it in their interest to invest in information acquisition and thus access the website.

Girls are more likely than boys to access the website. This chimes with the growing literature on the gender imbalance in participation in higher education (e.g., Bailey and Dynarksi 2011; Crawford and Greaves 2015). The results also indicate that students who talk a lot to teachers/parents/ friends about career-related information are more likely to access the website, reflecting the amenability of these students to acquiring more information through the website. Finally, being present oriented has a weak negative association with accessing the website, meaning that those with a high discount rate are less likely to access the website. The coefficient is statistically significant within the subsample of students in treatment schools that can be matched to administrative data.

It is notable that the $R^{2}$ decreases by over 50 percent between columns 2 and 3 (from .26 to .11). This reflects the importance of the schools that are lost when we use only those students and schools that can be matched to administrative data (i.e., which include the seven independent schools that are in the treatment) ${ }^{13}$ The extent of website use varies strongly between state schools and independent schools, with a much higher probability of access within the latter type. Specifically, the percentage of students accessing the website within treated schools in the state sector is 12 percent whereas it is 37 percent within independent schools. These schools are all fee paying and are attended by students with a high socioeconomic background. While the higher probability of access within these schools might reflect the demographics of these students (i.e., high socioeconomic background and high achieving), it might also reflect the

\footnotetext{
13 There are two additional state schools that do not match to the administrative data for other reasons.
} 
different characteristics of these schools. For example, they are better resourced with computers and so forth, and teachers potentially have more time to devote to career advice and guidance given that they do not have to apply the National Curriculum and are most likely dealing with a cohort of students with very high career aspirations.

In summary, taking treatment schools as a whole, we learn that the profile of those accessing the website is more likely to be female, self-confident, with a proficiency/taste for math, and from better-off family backgrounds. However, collectively the variables measure at most one-quarter of the variation in who accesses the website (i.e., col. 2).

\section{B. Effect of the Treatment}

In table 4, we show the intention to treat effect (col. 2), the estimated effect of the treatment on the treated (i.e., the IV estimate for who accesses the website, in col. 3), and the sensitivity of the regression for including additional controls for who accesses the website (col. 4) as described in the previous section. As expected, including these additional controls does not affect the estimated treatment on the treated effect. For reference, we also show the mean of the variables at baseline in the control group (col. 1). We report clustered standard errors computed using the cluster-correlated Huber-White estimator. ${ }^{14}$

We report five sets of variables here: those reflecting knowledge of student finance, the perceived importance of the financial constraint, the opportunity cost, knowledge about the benefits of staying on, and future intentions (although we leave discussion on expected wages and university fees to the section below).

The first thing to note is that the effect of the treatment on the treated is always substantially higher than the intention to treat effect. This shows that the effect of accessing the website was substantial for those who did access it. The effects of the treatment are evident for variables reflecting knowledge of student finance, the opportunity cost, knowledge about the benefits of further educational investment, and intentions to pursue postcompulsory education (though not going to university).

Starting with knowledge of student finance, the baseline survey revealed worrying gaps in students' knowledge of the basics. This is reflected in average responses at baseline in the control schools (col. 1). About half of the students in the control group did not know when university fees

\footnotetext{
${ }^{14}$ This is the case throughout our analysis. We have also estimated the intention to treat effects using the wild-bootstrap cluster- $t$ procedure, which is potentially important in trials in which the number of clusters is small (Cameron, Gelbach, and Miller 2008). When considering the estimated $p$-values of tests of the null that the coefficient is zero, results are mostly consistent with the results reported here (i.e., the $p$-value $<.05$ when results are significantly different from zero and is more sizable when they are not). However, there is some room for doubt within the subset of variables about "knowledge about benefits of staying on." This is reported in App. C.
} 
were paid or that student loans are granted on favorable terms. These misperceptions were largely corrected for those who accessed the website. Accessing the website increased the probability of knowing when university fees are paid by 41 percent (from a baseline of 45 percent) and increased the probability of students agreeing with the statement "student loans are a cheaper/better way to borrow money than other types of borrowing" by 25 percent (from a baseline of 51 percent).

About one-quarter of students at baseline were concerned about the opportunity cost of going to university, agreeing with the statement "going to university would mean waiting too long before I could earn a fulltime wage." The concern disappeared for about one-fifth of those who accessed the website.

While the majority ( 80 percent) of students had already grasped the employment-related benefits of staying on in education to age 18 or going to university (i.e., that the probability of getting a job would improve), only around half were aware that employment probabilities differ by institution attended and subject studied. The website both increased the perception of benefits in terms of the probability of getting a job and improved students' understanding that institutions can make a difference to expected earnings, although the experiment did not have a significant effect on students' understanding of the impact of subject choice on future earnings.

Despite the improvements in knowledge of the generosity of the student finance system and the benefits associated with staying on in fulltime education and/or attending university, students were just as likely as before to report being put off from staying on in education or going to university because of the cost and to report that "going to university is too expensive for me and my family" (i.e., the three variables reflecting the perceived importance of the financial constraint). The website also did not change their intention to apply to university at some stage. However, plans to stay on in full-time education beyond the age of 16 were very strongly and positively affected by access to the website.

Given that the experiment was effective in many dimensions, there are two potential puzzles: (1) Why did students' increased knowledge of (the favorable conditions of) student finance not reduce the perceived importance of the financial constraint of going to university? (2) Why did changing minds about the opportunity cost of going to university and benefits of staying on in education not change future intentions to apply to university? One explanation is that the perceptions and intentions of website users are not (at the margin) influenced by these considerations. Another explanation is that the announcement of the trebling of university fees and resulting controversy outweighed the influence of accessing the website.

To shed some light on this issue, we consider what happens to the control group between the first and second surveys (conducted 8-12 weeks apart). We regress each of the outcome variables considered above on 


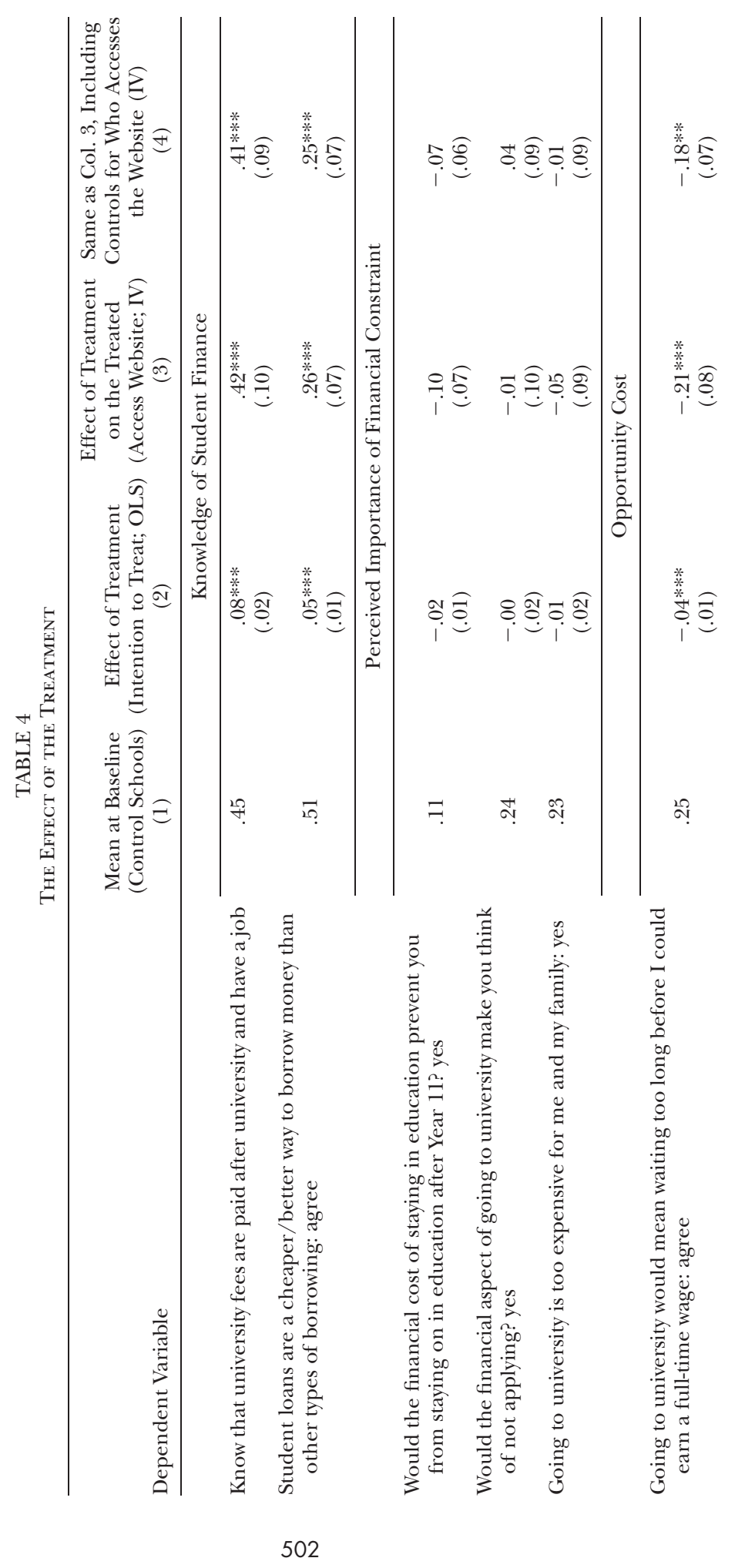




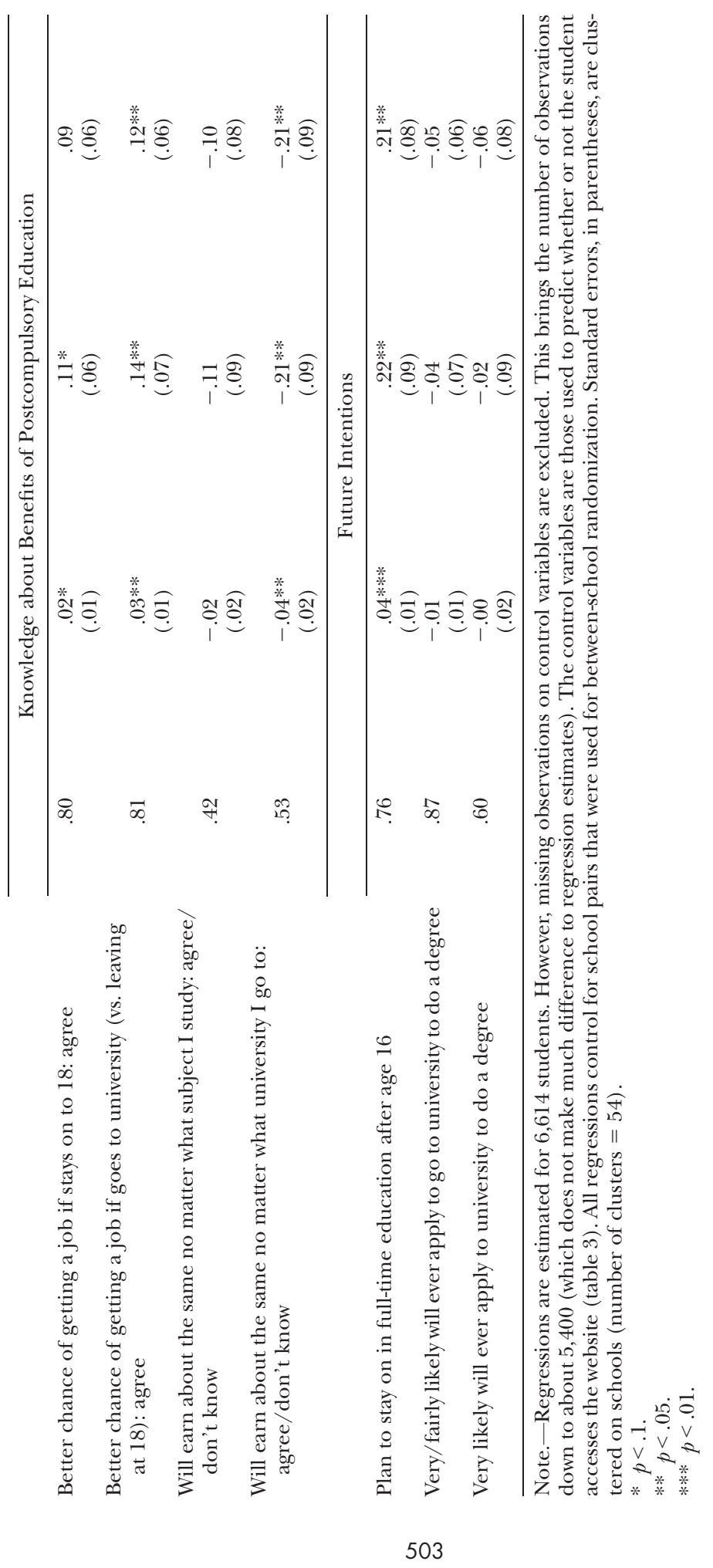


a time dummy for whether the question is being asked in the follow-up survey. The results are shown in table 5. Students' knowledge of when university fees are paid significantly improved between surveys. In figure 2 , we plot the kernel density function of students' estimate of the actual cost of university (fees only). This shows that all students (whether in treatment or control schools) had a better knowledge of the costs of university when asked about it a second time. ${ }^{15}$ This may reflect the flow of information between surveys (for everyone) or ease of access to this knowledge because of the announcement about the rise in tuition fees (in autumn 2010) and the extent of publicity about the changes (which we document above, but the most significant of which was the near trebling of student fees from $£ 3,300$ to $£ 9,000$ per year).

In table 5 , there is a big increase in the perceived financial constraint of going to university between surveys. This is consistent with the increased awareness of how much going to university would cost (i.e., in fig. 2). This is a plausible explanation for why the expectation of applying to university in the future decreased between surveys; while understanding of the nature of finance increased, students also became more concerned by the increase in fees.

However, it is interesting to note that many other variables are unchanged for the control group between the first and second waves. For example, none of the variables about the benefits of staying on in education change between the first and second waves for the control group, and they are unchanged in their intention to stay on in full-time education beyond the age of 16 . These are among the variables that should be influenced by our information campaign but not by government announcements on tuition fees or media coverage about the costs of going to university.

Thus, a plausible reason why our information campaign does not influence the treatment group about the costs of university, the perceived financial constraint implied by going to university, or intentions to apply to university is that any potential effect on these dimensions was outweighed by the controversy about the hike in tuition fees that took place over the time of our fieldwork.

\section{Measures of Expected Wages}

A key reason to go to university is, of course, the wage returns associated with higher education. Students were asked various questions of the following kind: "Imagine that you left school after Year 11 and tried to find a job. Think about the kinds of jobs you might be offered and what you might accept. What is your best guess of what you would earn per year at age 30?" They were asked similar questions for expected earnings con-

${ }^{15}$ Differences between treatment and control schools are not significant here. 
TABLE 5

What Happens to Control Group between Survey 1 and Survey 2?

\begin{tabular}{|c|c|c|}
\hline Dependent Variable & $\begin{array}{l}\text { Mean at Baseline } \\
\text { (Control Schools) }\end{array}$ & $\begin{array}{l}\text { Coefficient on Time Dummy } \\
\text { for Second Survey }\end{array}$ \\
\hline & \multicolumn{2}{|c|}{ Knowledge of Student Finance } \\
\hline $\begin{array}{l}\text { Know that university fees are paid } \\
\text { after university and have a job }\end{array}$ & .45 & $\begin{array}{l}.098^{* * *} \\
(.017)\end{array}$ \\
\hline \multirow[t]{2}{*}{$\begin{array}{l}\text { Student loans are a cheaper/better } \\
\text { way to borrow money than other } \\
\text { types of borrowing: agree }\end{array}$} & .51 & $\begin{array}{l}-.016 \\
(.015)\end{array}$ \\
\hline & \multicolumn{2}{|c|}{ Perceived Importance of Financial Constraint } \\
\hline $\begin{array}{l}\text { Would the financial cost of staying in } \\
\text { education prevent you from staying } \\
\text { on in education after Year 11? yes }\end{array}$ & .11 & $\begin{array}{l}.034 * * * \\
(.010)\end{array}$ \\
\hline \multicolumn{3}{|l|}{$\begin{array}{l}\text { Would the financial aspect of going to } \\
\text { university make you think of not }\end{array}$} \\
\hline \multirow[t]{2}{*}{$\begin{array}{l}\text { Going to university is too expensive for } \\
\text { me and my family: yes }\end{array}$} & .23 & $\begin{array}{l}.059^{* * *} \\
(.017)\end{array}$ \\
\hline & \multicolumn{2}{|c|}{ Opportunity Cost } \\
\hline \multirow[t]{2}{*}{$\begin{array}{l}\text { Going to university would mean waiting } \\
\text { too long before I could earn a } \\
\text { full-time wage: agree }\end{array}$} & .25 & $\begin{array}{l}.026^{* * * *} \\
(.010)\end{array}$ \\
\hline & \multicolumn{2}{|c|}{ Knowledge about Benefits of Postcompulsory Education } \\
\hline $\begin{array}{l}\text { Better chance of getting a job if stays } \\
\text { on to 18: agree }\end{array}$ & .80 & $\begin{array}{l}-.007 \\
(.010)\end{array}$ \\
\hline $\begin{array}{l}\text { Better chance of getting a job if goes to } \\
\text { university (vs. leaving at 18): agree }\end{array}$ & .81 & $\begin{array}{l}-.007 \\
(.010)\end{array}$ \\
\hline $\begin{array}{l}\text { Will earn about the same no matter what } \\
\text { subject I study: agree/don't know }\end{array}$ & .42 & $\begin{array}{l}-.010 \\
(.013)\end{array}$ \\
\hline \multirow[t]{2}{*}{$\begin{array}{l}\text { Will earn about the same no matter what } \\
\text { university I go to: agree/don't know }\end{array}$} & .53 & $\begin{array}{r}.015 \\
(.011)\end{array}$ \\
\hline & \multicolumn{2}{|c|}{ Future Intentions } \\
\hline $\begin{array}{l}\text { Plan to stay on in full-time education } \\
\text { after age } 16\end{array}$ & .76 & $\begin{array}{r}.006 \\
(.013)\end{array}$ \\
\hline $\begin{array}{l}\text { Very/fairly likely will ever apply to go to } \\
\text { university to do a degree }\end{array}$ & .87 & $\begin{array}{l}-.021 * * \\
(.009)\end{array}$ \\
\hline $\begin{array}{l}\text { Very likely will ever apply to university } \\
\text { to do a degree }\end{array}$ & .60 & $\begin{array}{l}-.032 * * \\
(.014)\end{array}$ \\
\hline
\end{tabular}

Note.--Regressions are estimated for 5,596 students in the control group. Standard errors, in parentheses, are clustered on schools (number of clusters $=27$ ).

$* p<.1$.

$* * p<.05$.

$* * * \quad p<.01$. 

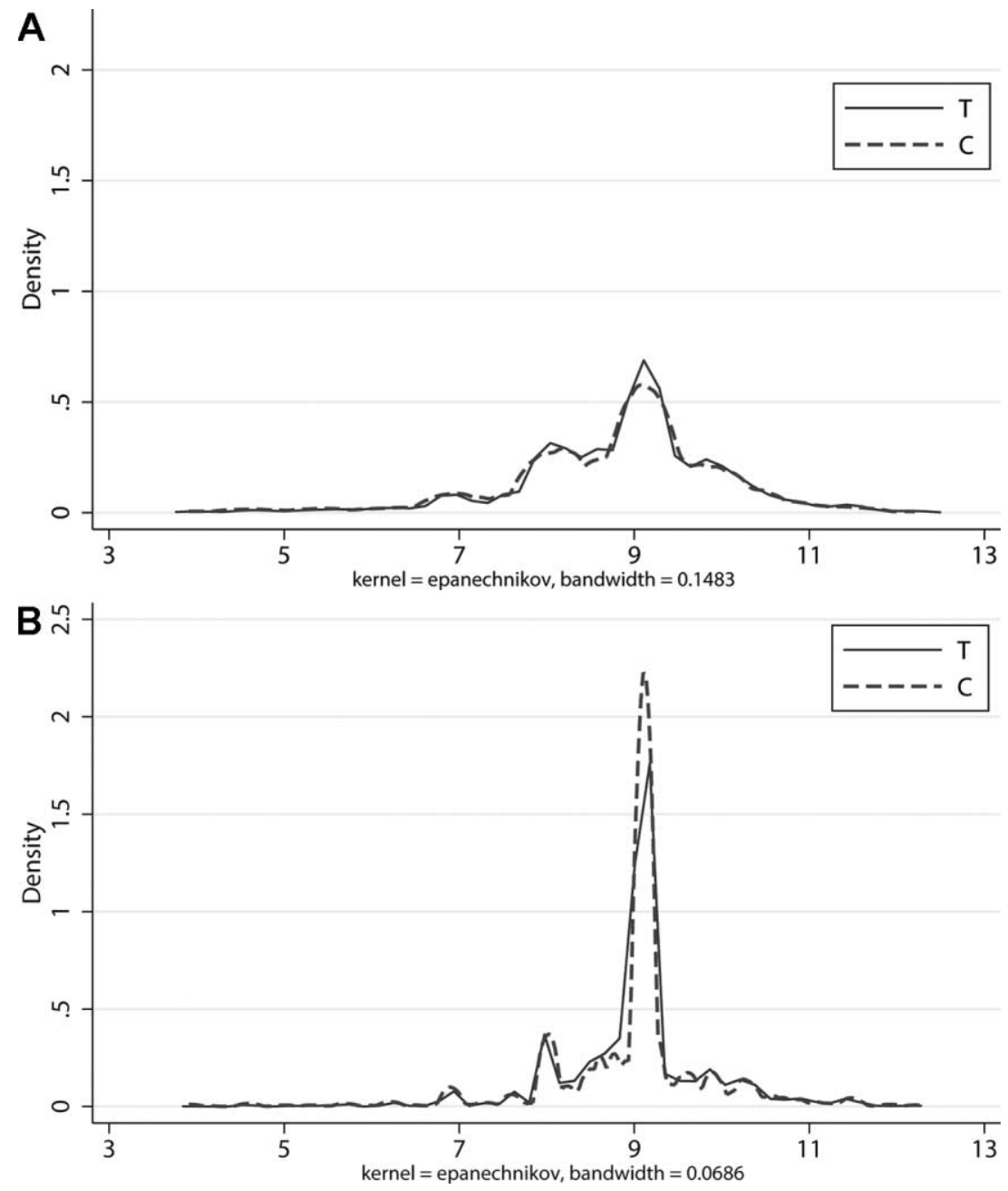

Figure 2.-Expected (log) yearly cost of going to university (fees only). Color version available as an online enhancement.

ditional on leaving full-time education at age 18 and age $21 .{ }^{16}$ However, our survey uncovers huge variation in students' estimates of the wage returns to education. This is shown in figure 3 , which illustrates the ratio of students' expected earnings for higher education relative to expected earnings if they were to leave school at age $16 .{ }^{17}$ As well as huge variation

${ }^{16}$ Where this information is missing, we impute a response as long as a response is given in at least one of six earnings questions in either survey 1 or survey 2 . After imputation, there are only 6 percent of students for whom we have no information. The kernel density plots exclude those with an implied estimated earnings ratio of over 10 (about 5 percent of the distribution in the case of expected earnings in higher education to leaving school after age 16).

${ }^{17}$ If we plot the ratio of expected earnings for leaving full-time education at 18 compared to 16 , we find that this is lower on average and the distribution is more compressed. The 

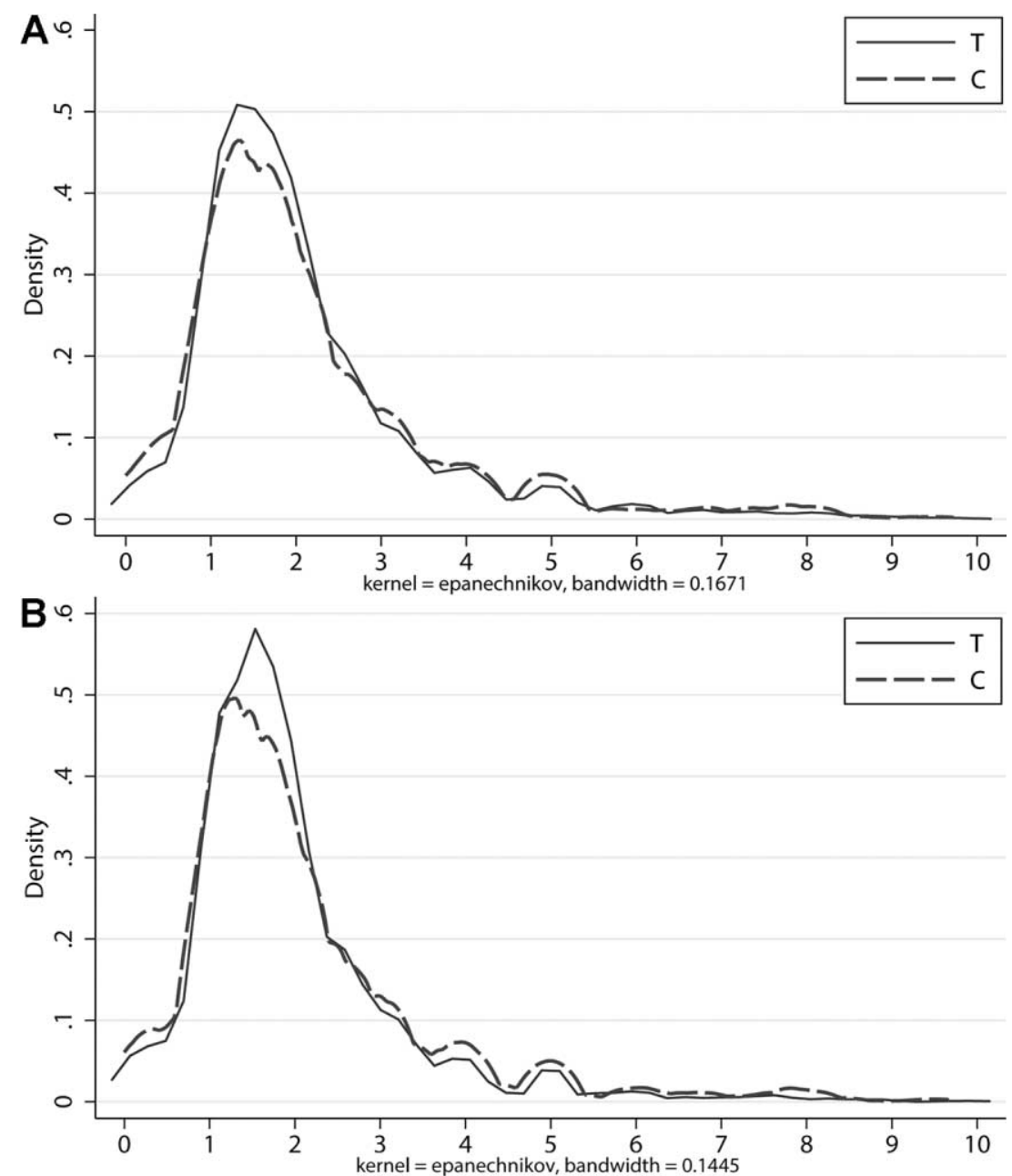

Figure 3.-Ratio of own expected earnings at age 30: higher education relative to leaving school at age 16. A, Treatment versus control schools, wave $1 . B$, Treatment versus control schools, wave 2. C, Website versus non-website users in treatment schools, wave 1. D, Website versus non-website users in treatment schools, wave 2 . Color version available as an online enhancement.

in responses, there is a long right tail in the distribution: many students vastly overestimate returns (which is consistent with the literature). However, the median student does have a reasonable idea (which is also shown in table 2). The figures suggest that the treatment may have increased the density at the middle of the distribution (especially for students who accessed the website), although coefficients do not come out as significant

distribution is similar in treatment and control schools and there is no treatment effect. We also asked students about expected earnings for other people (not themselves). Results were very similar and are not discussed here. 

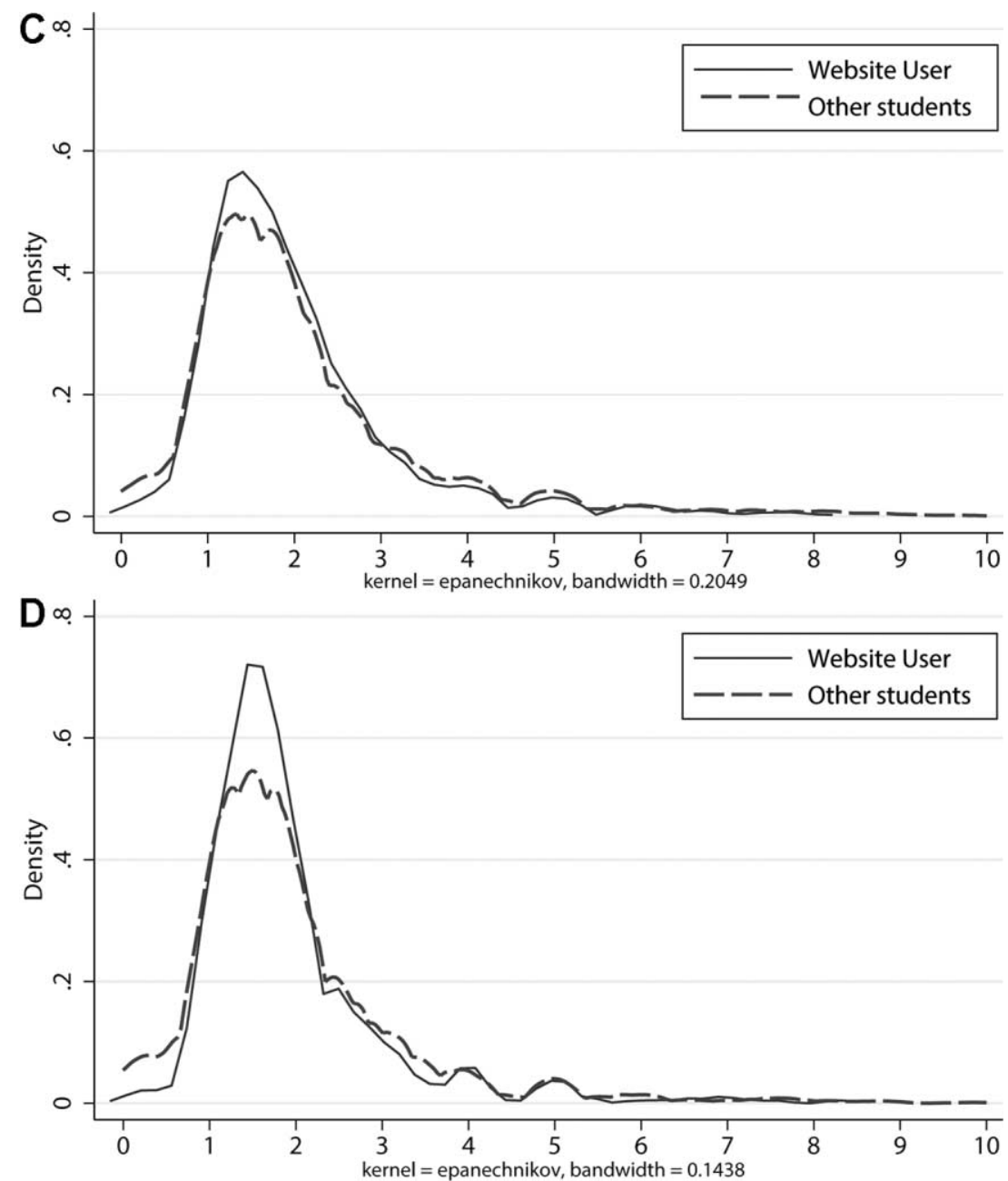

Figure 3 (Continued)

in regressions. Our treatment materials also provided information on earnings by subject of degree. However, we did not find any pattern of results suggesting that the information campaign had changed the preferred subject of study, and we do not focus on these results (which are available on request).

\section{Future Intentions}

We now look more closely at variables that are associated with future intentions about educational investment decisions: whether the student plans to stay on in full-time education beyond the age of 16 and whether he or she is likely to apply to attend university at some stage. 
In table 6 , we show the intention to treat effect for both of these variables, including other controls that we expect to be important (as motivated in Sec. V). We also (again) show the treatment on the treated effect in both cases (cols. 3 and 4). The point of showing these regressions is simply to investigate the relevance of other variables likely to influence the educational investment decision, alongside the effects of the treatment, which we know had a strong positive impact on students' reported intentions to stay on after age 16 , although not on intentions to go to university. This helps to establish that the variables measuring future intentions have real informational content.

The IV estimate (of the treatment on the treated) is not directly comparable to coefficients for these other variables because it is a LATE (i.e., is relevant only for those students who accessed the website). Furthermore, the other variables are only proxies for underlying factors (in a

TABLE 6

FutURE INTENTIONS

\begin{tabular}{|c|c|c|c|c|}
\hline & \multicolumn{2}{|c|}{$\begin{array}{l}\text { Whether Plans to Stay on in } \\
\text { Full-Time Education after } 16\end{array}$} & \multicolumn{2}{|c|}{$\begin{array}{l}\text { Whether Plans to Apply to } \\
\text { University at Some Stage }\end{array}$} \\
\hline & $\begin{array}{l}\text { OLS } \\
\text { (Intention } \\
\text { to Treat) } \\
\quad(1)\end{array}$ & $\begin{array}{c}\text { Treatment on } \\
\text { the Treated } \\
\text { (IV: Website User) } \\
\text { (2) }\end{array}$ & $\begin{array}{l}\text { OLS } \\
\text { (Intention } \\
\text { to Treat) } \\
\quad(3)\end{array}$ & $\begin{array}{c}\text { Treatment on } \\
\text { the Treated } \\
\text { (IV: Website User) } \\
\text { (4) }\end{array}$ \\
\hline Treatment & $\begin{array}{l}.04 * * * \\
(.01)\end{array}$ & $\begin{array}{l}.21 * * \\
(.08)\end{array}$ & $\begin{array}{c}-.01 \\
(.01)\end{array}$ & $\begin{array}{l}-.05 \\
(.06)\end{array}$ \\
\hline Male & $\begin{array}{l}-.07 * * * \\
(.02)\end{array}$ & $\begin{array}{l}-.05^{* * * *} \\
(.02)\end{array}$ & $\begin{array}{l}-.04 * * \\
(.02)\end{array}$ & $\begin{array}{l}-.04 * * \\
(.02)\end{array}$ \\
\hline Books in the home & $\begin{array}{l}.03^{* * * *} \\
(.01)\end{array}$ & $\begin{array}{l}.03^{* * * *} \\
(.01)\end{array}$ & $\begin{array}{l}.02 * * * \\
(.01)\end{array}$ & $\begin{array}{l}.02 * * * \\
(.01)\end{array}$ \\
\hline $\begin{array}{l}\text { Talks a lot to teachers/ } \\
\text { friends/family about } \\
\text { careers }\end{array}$ & $\begin{array}{l}.02^{*} \\
(.01)\end{array}$ & $\begin{array}{l}.02^{*} \\
(.01)\end{array}$ & $\begin{array}{l}.04 * * * \\
(.01)\end{array}$ & $\begin{array}{l}.04 * * * \\
(.01)\end{array}$ \\
\hline Good at math & $\begin{array}{l}.09 * * * \\
(.02)\end{array}$ & $\begin{array}{l}.09 * * * \\
(.02)\end{array}$ & $\begin{array}{l}.06^{* * *} \\
(.02)\end{array}$ & $\begin{array}{l}.06 * * * \\
(.02)\end{array}$ \\
\hline Good at English & $\begin{array}{l}.04 * * * \\
(.02)\end{array}$ & $\begin{array}{l}.05^{* * * *} \\
(.02)\end{array}$ & $\begin{array}{l}.04 * * \\
(.02)\end{array}$ & $\begin{array}{l}.04 * * \\
(.02)\end{array}$ \\
\hline Likes math & $\begin{array}{l}.02 \\
(.02)\end{array}$ & $\begin{array}{l}.02 \\
(.02)\end{array}$ & $\begin{array}{l}.03^{* *} \\
(.01)\end{array}$ & $\begin{array}{l}.03 * * \\
(.01)\end{array}$ \\
\hline Likes English & $\begin{array}{l}.01 \\
(.01)\end{array}$ & $\begin{array}{l}.01 \\
(.01)\end{array}$ & $\begin{array}{l}.00 \\
(.01)\end{array}$ & $\begin{array}{l}.00 \\
(.01)\end{array}$ \\
\hline Locus of control & $\begin{array}{l}.08^{* * * *} \\
(.01)\end{array}$ & $\begin{array}{l}.08^{* * *} \\
(.01)\end{array}$ & $\begin{array}{l}.05^{* * *} \\
(.01)\end{array}$ & $\begin{array}{l}.05 * * * \\
(.01)\end{array}$ \\
\hline Self-esteem & $\begin{array}{l}.01 \\
(.01)\end{array}$ & $\begin{array}{l}.01 \\
(.01)\end{array}$ & $\begin{array}{l}.03 * * * \\
(.01)\end{array}$ & $\begin{array}{l}.03 * * * \\
(.01)\end{array}$ \\
\hline Present oriented & $\begin{array}{l}-.05^{* * *} \\
(.01)\end{array}$ & $\begin{array}{l}-.05^{* * *} \\
(.01)\end{array}$ & $\begin{array}{l}-.02 * * * \\
(.01)\end{array}$ & $\begin{array}{l}-.02 * * * \\
(.01)\end{array}$ \\
\hline $\begin{array}{l}\text { Observations } \\
R^{2}\end{array}$ & $\begin{array}{l}5,366 \\
.12\end{array}$ & $\begin{array}{l}5,366 \\
.10\end{array}$ & $\begin{array}{c}5,380 \\
10\end{array}$ & $\begin{array}{l}5,380 \\
10\end{array}$ \\
\hline
\end{tabular}

Note.-See note for table 4 .

$* p<.1$.

$* * p<.05$.

$* * * p<.01$. 
reduced-form context). Nonetheless, it is of interest to show the association between these variables and decisions to stay on.

The regressions show that boys are less likely both to intend to stay on in full-time education and to apply to university at some stage. They also show that students from more advantaged family backgrounds are more likely to stay on in full-time education and apply to university at some stage. This is not surprising and is in line with what is actually observed with regard to both dropout and university attendance (e.g., Maania and Kalbb 2007; Chowdry et al. 2013; Murnane 2013). We find the variables that we expect to positively influence the intention to stay on in education after 16 and apply to university do so, namely, the measures of cognitive ability (though note that self-assessed ability is relevant here rather than whether the student likes math, in contrast to accessing the website where only liking math was relevant), locus of control (though not self-confidence), and finding out about the consequences of educational choices by talking to teachers/family/friends. Measures of cognitive ability are also associated with these educational intentions. Finally, being present oriented (i.e., higher discount rates) is negatively associated with the intention to stay on in education, again as we would expect.

This exercise shows that variables expected to influence the intention to stay on in education do so in the expected direction, as they have been shown to in many other studies about educational investment decisions. Thus, it seems likely that variables that measure future intentions do have real informational content.

\section{E. Heterogeneity}

Finally, we consider whether there is a heterogeneous effect of the treatment on the intention to stay on in full-time education beyond the age of 16 . We focus on this measure because of its potential relationship with the actual staying on decision and because this is strongly influenced by accessing the website. We consider whether effects are different for males or females and whether they are different for those with higher and lower family resources (proxied by books in the household). The sample is fairly evenly split in these dimensions (although there are fewer boys than girls). We choose these groups because they have been identified in the literature as particularly vulnerable when it comes to staying on in education. Heterogeneity by gender is of interest because boys are more likely to drop out of education before girls (e.g., as discussed by Goldin and Katz [2008] and Murnane [2013]). Socioeconomic background is also strongly associated with the staying on decision, with youths from disadvantaged backgrounds more likely to drop out (e.g., Kearney and Levine 2015).

In table 7, we estimate the effect of the treatment on the treated for four different subgroups: those from lower socioeconomic groups (i.e., proxied by below-median books in the home), those from higher socioeconomic groups, boys, and girls. In column 1, we show the intention 
TABLE 7

Whether Plans to Stay on in Post-16 Full-Time Education: Heterogeneity in the EfFects of Accessing the Website

\begin{tabular}{|c|c|c|c|c|c|}
\hline \multirow[b]{2}{*}{ Subgroup } & \multirow[b]{2}{*}{$\begin{array}{l}\text { Baseline: } \\
\text { Intention to } \\
\text { Stay on in } \\
\text { Full-Time } \\
\text { Education } \\
\text { Post-16 } \\
\text { (1) }\end{array}$} & \multirow[b]{2}{*}{$\begin{array}{l}\% \text { Accessing } \\
\text { Website } \\
\text { in Treatment } \\
\text { Schools } \\
(2)\end{array}$} & \multicolumn{3}{|c|}{ IV Estimate: Accessing the Website } \\
\hline & & & $\begin{array}{c}\text { No } \\
\text { Controls } \\
(3)\end{array}$ & $\begin{array}{c}\text { With } \\
\text { Controls } \\
\text { (4) }\end{array}$ & $\begin{array}{c}\text { With } \\
\text { Controls } \\
\text { and for } \\
\text { Baseline } \\
\text { Response } \\
\text { (5) }\end{array}$ \\
\hline $\begin{array}{l}\text { Lower income: } \\
\text { below median of } \\
\text { books in household } \\
(N=2,601)\end{array}$ & .72 & .11 & $\begin{array}{l}.60^{* * *} \\
(.16)\end{array}$ & $\begin{array}{l}.52^{* * * *} \\
(.16)\end{array}$ & $\begin{array}{l}.45^{* * *} \\
(.11)\end{array}$ \\
\hline $\begin{array}{l}\text { Higher income: } \\
\text { above median of } \\
\text { books in household } \\
(N=2,741)\end{array}$ & .85 & .21 & $\begin{array}{l}.05 \\
(.06)\end{array}$ & $\begin{array}{l}.06 \\
(.05)\end{array}$ & $\begin{array}{l}.08^{*} \\
(.05)\end{array}$ \\
\hline Boys $(N=2,354)$ & .76 & .16 & $\begin{array}{l}.29 * * \\
(.14)\end{array}$ & $\begin{array}{l}.28 * * \\
(.13)\end{array}$ & $\begin{array}{l}.25^{* * *} \\
(.11)\end{array}$ \\
\hline Girls $(N=3,012)$ & .80 & .17 & $\begin{array}{l}.18 \\
(.11)\end{array}$ & $\begin{array}{l}.14 \\
(.11)\end{array}$ & $\begin{array}{l}.15^{*} \\
(.09)\end{array}$ \\
\hline
\end{tabular}

Note.-Regression estimates are shown in cols. 3, 4, and 5. The regressions are separately estimated for each subgroup. All regressions control for school pairs that were used for between-school randomization. Standard errors, in parentheses, are clustered on school. $* p<.1$.

$* * p<.05$.

$* * * p<.01$.

to stay on in full-time education at baseline for each of these groups. The gap between low and high socioeconomic groups is high (13 percentage points), and there is also a gap between boys and girls (4 percentage points), in line with the literature described above. In column 2, we show the proportions of each group that access the website (in treatment schools). Of those from lower socioeconomic backgrounds, about 11 percent access the website, compared to 21 percent of those from higher socioeconomic backgrounds. The proportion of boys accessing the website is only a little lower ( 1 percentage point) than for girls.

In columns 3, 4, and 5, we show IV estimates of the treatment on the treated for each of these four groups. In column 3, we estimate the IV regressions without including any other controls (apart from school pairs that were used for randomization). In column 4 , we include controls used to predict access to the website. In column 5 , we also include a control for the baseline response of students (i.e., whether or not they intended to stay on in full-time education). The coefficients do not change very much between specifications, but the precision improves when the baseline response is included.

The regressions show that accessing the website has an effect for all groups, even though it is statistically significant for all groups only in the 
final specification. However, it is striking that the estimated effect is about five times higher for students from lower socioeconomic backgrounds who accessed the website, compared to those from higher socioeconomic groups, and it is about 60 percent higher for boys compared to girls. This suggests that the information treatment is potentially most useful and influential to groups most at risk of dropping out. However, since these groups are less likely to access the information, it might still be ineffectual unless they are encouraged to access such information.

\section{Conclusion}

Students appear to drop out of education even though there is the potential for high returns had they invested more in postcompulsory education. A contributory factor may be that they have insufficient knowledge about the costs and benefits of education at an appropriate time in their schooling (which might potentially influence their effort and motivation). In this paper, we find that many students in London schools do not know some basic facts about the costs and benefits of pursuing postcompulsory education when in their penultimate year of compulsory schooling. A simple and inexpensive information campaign can be effective for those choosing to access the information, at least for influencing short-term intentions. Of course, in the future, it will be interesting to consider to what extent this intervention has an impact on actual behavior. In the future, administrative data will allow us to consider this for about 60 percent of the sample (mostly students who attended state schools that can be linked to administrative data).

This study illustrates that the mere existence of cheaply available information does not mean that individuals will actually choose to acquire it. Only 16 percent of students in treated schools chose to access the website, even though we tried to encourage them to do so through various means and got their teachers involved. Factors positively associated with accessing the website include student ability and preferences for education, coming from a higher socioeconomic group (reflected both by books in the home and going to an independent school), and having a lower discount rate. These are among the same factors known to influence the human capital investment decision. The literature on financial literacy and optimal portfolio management suggests that investing in financial knowledge is itself a form of human capital investment (which is correlated with preexisting human capital). Individuals invest in financial knowledge to the point where the marginal cost of doing so equals the marginal benefit. The factors we find to be associated with accessing the website (e.g., ability, family resources, the discount rate) are the same variables one would expect to influence human capital decisions as well as other investment decisions more broadly.

Even though access to the website is free, it does involve an opportunity cost of time and an effort in processing information (the cost of which is emphasized by literature on rationally inattentive agents). Thus, perhaps 
unsurprisingly, our study shows that it can be difficult to persuade teenagers to take an interest. For those who did take an interest and used the website, our study shows a positive effect on their knowledge and on the intention to pursue postcompulsory education. However, we also show that those less likely to access the information (those from lower socioeconomic groups and boys) have more to benefit from doing so, as effect sizes are much larger for these groups. Thus, our experiment shows that the short-term impact of accessing information (via the website) had a higher effect on those most at risk at dropping out of full-time education after finishing their compulsory years of schooling, namely, boys and those from lower socioeconomic groups. This is an important issue for policy makers who are concerned with designing cost-effective ways of providing information to the population at large and also to those tasked with widening participation in higher education - a key policy goal in the United Kingdom and United States. Our findings suggest that simply providing information on the costs and benefits of education (e.g., on websites or through the media), even in a very simple format, will not be effective for students who perceive (rightly or wrongly) that it is too difficult or costly to process the information and take account of it in their situations. One solution is to tailor information more closely to individual situations and provide it at the right time (which is not straightforward at a large scale). Another solution is to ensure that career advice and guidance are properly embedded in the high school curriculum, thus reducing the scope for making poorly informed decisions about postcompulsory education.

\section{Appendix A}

\section{Questions Used as Outcome Variables}

Full questionnaires are downloadable on http://www.whats4.me.uk.

Knowledge of Student Finance

D3. When do you think most people pay their university fees? (tick one box): before the start of each year at university; immediately after they finish university; when they finish university and have a job; don't know.

A1. Student loans a cheaper/better way to borrow money than other types of borrowing (e.g. credit cards). Strongly agree; agree; disagree; strongly disagree; don't know.

Perceived Importance of Financial Constraint

D2. Would the financial cost of staying on in education prevent you from staying on in education after Year 11? Yes; no; don't know.

D5. Would the financial aspect of going to university (that is the cost of fees and living expenses) make you think of NOT applying? Yes; no; don't know.

A1. Going to university is too expensive for me and my family. Strongly agree; agree; disagree; strongly disagree; don't know. 
Opportunity Cost

A1. Going to university would mean waiting too long before I could earn a fulltime wage. Strongly agree; agree; disagree; strongly disagree; don't know.

\section{Knowledge about Benefits of Staying On}

C7. Do you think that a person has a better or worse chance of getting a job if he/ she stays in education up to age 18 compared to leaving school after Year 11? Would you say it is: much worse; worse; same; better; much better.

C8. Do you think that a person has a better or worse chance of getting a job if he/she goes to university compared to leaving education at age 18? Would you say it is: much worse; worse; same; better; much better.

A1. If I get a university degree, I will earn about the same no matter what subject I study: strongly agree; agree; disagree; strongly disagree; don't know.

A1. If I get a university degree, I will earn about the same no matter what university I go to: strongly agree; agree; disagree; strongly disagree; don't know.

\section{Estimates of Costs and Benefits}

D3. What do you think is the yearly cost of sending a person to university? (just in terms of tuition fees).

E1. Imagine that you left school after Year 11 and tried to find a job. Think about the kinds of jobs you might be offered and what you might accept. What is your best guess of what you would earn per year at age 30 ?

E2. Imagine that you continued at school after Year 11 or went to a College of Further Education (or a Sixth Form College). And then, tried to find a job at around 18. Think about the kinds of job you might be offered and what you might accept. What is your best guess of what you would earn per year at age 30 ?

E3. Imagine that you continued in education and went to university (or other type of higher education) for 3 or 4 years. Think about the kinds of job you might be offered and what you might accept after this (leaving full-time education at about age 21). What is your best guess of what you would earn per year at age 30 ?

Future Intentions

C1. When you are 16 and have finished Year 11 at school, what do you plan to do next? Tick one box. Stay in full-time education; start working full-time; start learning a trade/start work-based training; something else; don't know.

C4. How likely do you think it is that you will ever apply to go to university to do a degree? Would you say it is: very likely, fairly likely, not very likely, not at all likely, don't know.

\section{Appendix B}

\section{Variable Descriptions}

Full questionnaires are downloadable on http://www.whats4.me.uk. 
Books in the Home

F4: How many books are there in your home? Categories are: $0-10$ books; $11-25$ books; 26-100 books, 101-200 books; 201-500 books; more than 500 books.

In the analysis these categories are ranked $0-6$ and standardized to have mean zero and standard deviation one.

Talks a Lot to Teachers/Friends/Family about Careers

B1: Thinking about plans for studying in the future, how often to you talk about these things to the following people? ( 5 options given from "not at all" to "a lot"): With teachers as part of a lesson; with teachers outside lessons; with a careers advisor who is not one of your teachers; with members of your family; with friends.

In this analysis "talks a lot" $=1$ if the student says they talk a lot to teachers or friends or family.

Good at Math/Good at English

A4. How good would you say you were at each of the following subjects? ... Options provided are as follows: very good, fairly good; not very good; no good at all, do not take this subject.

In the analysis, "good at Maths" (English) $=1$ if the student says they are very good or fairly good at math (English).

\section{Likes Math/Likes English}

A3. For each subject listed below, please tick one of the boxes according to how much you like/dislike each subject. Options provided are as follows: like it a lot; like it a little; don't like it very much; don't like it at all; do not take this subject.

In the analysis, "likes Maths" (English) $=1$ if the student says they like math (English) a lot or a little.

\section{Locus of Control and Self-Concept (Referred to as "Self-Esteem")}

G1. How do you feel about the following (13) statements? These questions were adopted from the National Education Longitudinal Survey of 1988 (NELS: 88). Items were drawn from the NELS:88 questionnaire, as applied by the Early Child Longitudinal Survey (K-8). Students were asked the degree to which they agreed with 13 statements about themselves and about how much control they felt they had over their own lives. They rated whether they "strongly agree," "agree," "disagree," or "strongly disagree" with each item. Scores were calculated with the same procedures at NELS:88. Some items were positively worded and some were negatively worded.

In the analysis, standardized scores for locus of control and self-esteem are included, with mean zero and standard deviation one.

Present Oriented

I1. If you were offered $£ 1,000$ today or $£ 1,100$ in one year’s time, what would you prefer? 


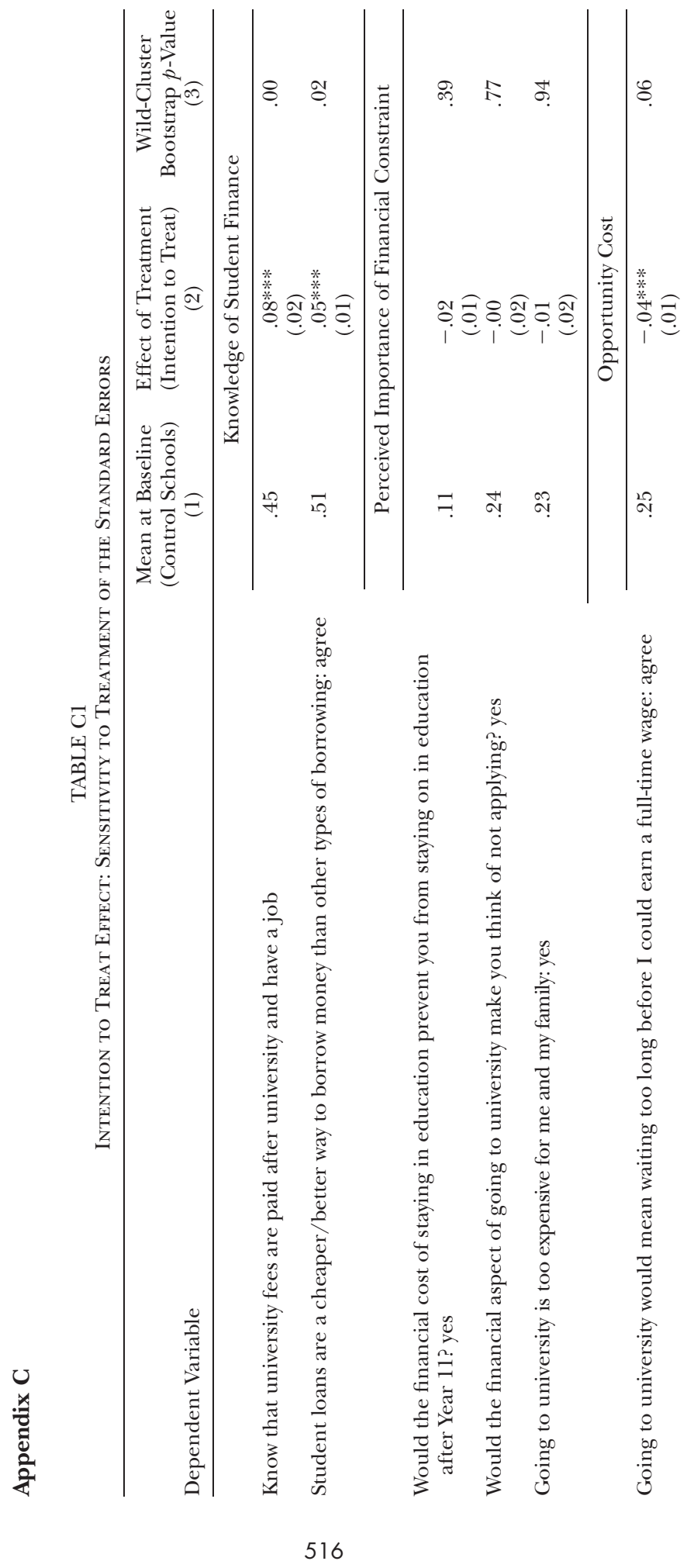




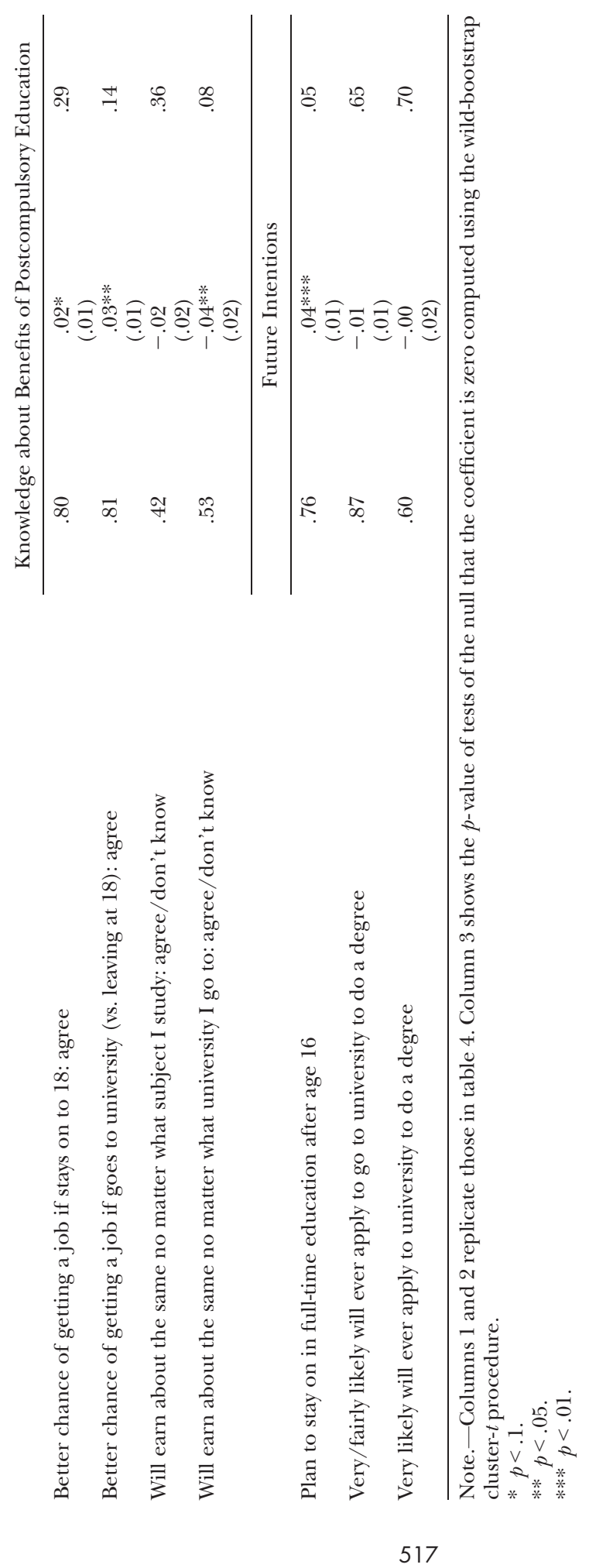




\section{References}

Angrist, J., and V. Lavy. 2009. "The Effects of High Stakes High School Achievement Awards: Evidence from a Randomized Trial.” A.E.R. 99 (4): 303-31.

Bailey, M. J., and S. Dynarski. 2011. "Gains and Gaps: Changing Inequality in U.S. College Entry and Completion.” Working Paper no. 17633, NBER, Cambridge, MA.

Bettinger, E., B. Long, P. Oreopoulos, and L. Sanbonmatsu. 2009. "The Role of Simplification and Information in College Decisions: Results from the H\&R Block FAFSA Experiment." Working Paper no. 15361, NBER, Cambridge, MA.

Betts, J. R. 1996. "What Do Students Know about Wages? Evidence from a Survey of Undergraduates." J. Human Resources 31 (1): 27-56.

Blundell, R., L. Dearden, and B. Sianesi. 2005. "Evaluating the Effect of Education on Earnings: Models, Methods and Results from the National Child Development Survey." J. Royal Statis. Soc., ser. A, 168:473-512.

Booij, A., E. Leuven, and H. Oosterbeek. 2012. "The Role of Information in the Take-Up of Student Loans." Econ. Educ. Rev. 31:33-44.

Cameron, C., J. Gelbach, and D. Miller. 2008. "Bootstrap-Based Improvements for Inference with Clustered Errors." Rev. Econ. and Statis. 90:414-27.

Chowdry, H., C. Crawford, L. Dearden, A. Goodman, and A. Vignoles. 2013. "Widening Participation in Higher Education: Analysis Using Linked Administrative Data.” J. Royal Statis. Soc., ser. A, 176 (2): 431-57.

Crawford, C., and E. Greaves. 2015. "Socio-economic, Ethnic and Gender Differences in HE Participation.” Research Paper no. 186, Dept. Bus., Innovation, and Skills, London.

Dominitz, J., and H. Manski. 1996. "Eliciting Student Expectations of the Returns to Schooling." J. Human Resources 31 (1): 1-26.

Duflo, E., and E. Saez. 2003. "The Role of Information and Social Interactions in Retirement Plan Decisions: Evidence from a Randomized Experiment." Q.J.E. 118 (3): 815-42.

Ehrlich, I., W. Hamlen Jr., and Y. Yin. 2008. “Asset Management, Human Capital, and the Market for Risky Assets." J. Human Capital 2:217-61.

Ehrlich, I., J. K. Shin, and Y. Yin. 2011. "Private Information, Human Capital, and Optimal 'Home Bias' in Financial Markets.” J. Human Capital 5:255-301.

Fryer, R. G. 2013. "Information and Student Achievement: Evidence from a Cellular Phone Experiment.” Working Paper no. 19113, NBER, Cambridge, MA.

Goldin, C. D., and L. F. Katz. 2008. The Race between Education and Technology. Cambridge, MA: Belknap Press, Harvard Univ. Press.

Goux, D., M. Gurgand, and E. Maurin. 2014. "Adjusting Your Dreams? The Effect of Schools and Peers on Dropout Behaviour.” IZA Discussion Paper no. 7948, Inst. Study Labor, Bonn.

Heckman, J., J. Stixrud, and S. Urzua. 2006. "The Effects of Cognitive and Noncognitive Abilities on Labor Market Outcomes and Social Behavior." J. Labor Econ. 24 (3): 411-82.

Hoxby, C., and S. Turner. 2013. "Expanding College Opportunities for HighAchieving, Low Income Students.” Discussion Paper no. 12-014, Inst. Econ. Policy Res., Stanford Univ.

Hupkau, C., S. McNally, J. Ruiz-Valenzuela, and G. Ventura. 2016. "Post-compulsory Education in England: Choices and Implications." Discussion Paper no. 001, Centre Vocational Educ. Res., London School Econ.

Jensen, R. 2010. "The (Perceived) Returns to Education and the Demand for Schooling." Q.J.E. 125 (2): 515-48.

Kearney, Melissa S., and Phillip B. Levine. 2015. "Media Influences on Social Outcomes: The Impact of MTV's 16 and Pregnant on Teen Childbearing." A.E.R. 105 (12): 3597-3632. 
Liebman, J. B., and E. F. P. Luttmer. 2010. "Would People Behave Differently If They Better Understood Social Security? Evidence from a Field Experiment." Working paper, NBER, Cambridge, MA.

Lusardi, A., and O. S. Mitchell. 2014. "The Economic Importance of Financial Literacy: Theory and Evidence.” J. Econ. Literature 52 (1): 5-44.

Maania, S. A, and G. Kalbb. 2007. "Academic Performance, Childhood Economic Resources, and the Choice to Leave School at Age 16." Econ. Educ. Rev. 26 (3): 361-74.

Matêjka, F., and A. McKay. 2015. "Rational Inattention to Discrete Choices: A New Foundation for the Multinomial Logit Model.” A.E.R. 105 (1): 272-98.

Murnane, R. J. 2013. "U.S. High School Graduation Rates: Patterns and Explanations." J. Econ. Literature 51 (2): 370-422.

Nguyen, T. 2008. "Information, Role Models and Perceived Returns to Education: Experimental Evidence from Madagascar.” Working paper, Massachusetts Inst. Tech.

Oreopoulos, P., and R. Dunn. 2013. "Information and College Access: Evidence from a Randomized Field Experiment." Scandinavian J. Econ. 115 (1): 3-26.

Rosen, S. 1977. "Human Capital: A Survey of Empirical Research." Res. Labor Econ. $1: 3-40$.

Scott-Clayton, J. 2012. "Information Constraints and Financial Aid Policy." Working Paper no. 17811, NBER, Cambridge, MA.

Sims, C. A. 2010. "Rational Inattention and Monetary Economics." In Handbook of Monetary Economics, vol. 3A, edited by B. M. Friedman and M. Woodford, 15581. Amsterdam: Elsevier.

Wiswall, M., and B. Zafar. 2011. "Determinants of College Major Choice: Identification Using an Information Experiment." Staff Report no. 500, Fed. Reserve Bank New York. 